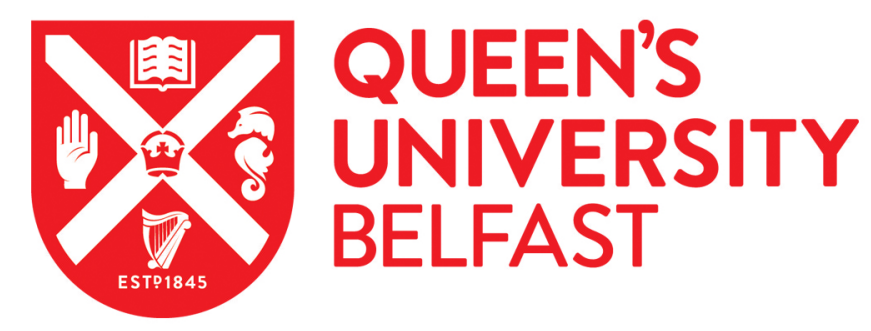

\title{
The Role of Peptidyl Prolyl Isomerases in Aging and Vascular Diseases
}

McClements, L., Annett, S., Yakkundi, A., \& Robson, T. (2015). The Role of Peptidyl Prolyl Isomerases in Aging and Vascular Diseases. Current Molecular Pharmacology, 8(2), 165-179.

https://doi.org/10.2174/1874467208666150519115729

Published in:

Current Molecular Pharmacology

Document Version:

Peer reviewed version

Queen's University Belfast - Research Portal:

Link to publication record in Queen's University Belfast Research Portal

Publisher rights

The published manuscript is available at EurekaSelect via

http://www.eurekaselect.com/openurl/content.php?genre=article\&doi=10.2174/1874467208666150519115729\#sthash.qB2bL7lt.dpuf

\section{General rights}

Copyright for the publications made accessible via the Queen's University Belfast Research Portal is retained by the author(s) and / or other copyright owners and it is a condition of accessing these publications that users recognise and abide by the legal requirements associated with these rights.

Take down policy

The Research Portal is Queen's institutional repository that provides access to Queen's research output. Every effort has been made to ensure that content in the Research Portal does not infringe any person's rights, or applicable UK laws. If you discover content in the Research Portal that you believe breaches copyright or violates any law, please contact openaccess@qub.ac.uk. 


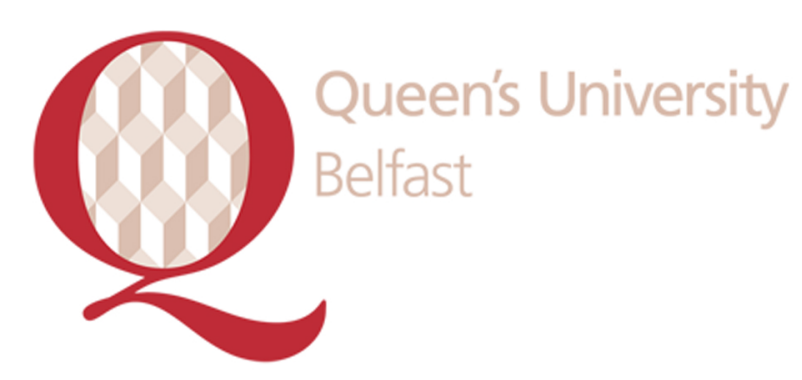

\section{Queen's University Belfast - Research Portal}

\section{The Role of Peptidyl Prolyl Isomerases in Aging and Vascular Diseases}

McClements, L., Annett, S., Yakkundi, A., \& Robson, T. (2015). The Role of Peptidyl Prolyl Isomerases in Aging and Vascular Diseases. Current Molecular Pharmacology, 8. 10.2174/18744667208666150519115729

\section{Published in:}

Current Molecular Pharmacology

\section{Document Version:}

Author final version (often known as postprint)

\section{Link:}

Link to publication record in Queen's University Belfast Research Portal

\section{Publisher rights}

Copyright 2015 Bentham Science

EMBARGO -12 months

The published manuscript is available at EurekaSelect via http://www.eurekaselect.com/openurl/content.php?genre=article\&doi=[insert DOI]."

\section{General rights}

Copyright for the publications made accessible via the Queen's University Belfast Research Portal is retained by the author(s) and / or other copyright owners and it is a condition of accessing these publications that users recognise and abide by the legal requirements associated with these rights.

\section{Take down policy}

The Research Portal is Queen's institutional repository that provides access to Queen's research output. Every effort has been made to ensure that content in the Research Portal does not infringe any person's rights, or applicable UK laws. If you discover content in the Research Portal that you believe breaches copyright or violates any law, please contact openaccess@qub.ac.uk. 
The Role of Peptidyl Prolyl Isomerases in Aging and Vascular Diseases

Lana McClements, Stephanie Annett, Anita Yakkundi and Tracy Robson*

School of Pharmacy, Queen's University Belfast, United Kingdom

*Corresponding Author: Tracy Robson, Professor, School of Pharmacy, Queen's University

Belfast, 97 Lisburn Road, Belfast, UK, BT9 7BL. Phone: +44/02890972360. Fax: +44/02890247794. Email: t.robson@qub.ac.uk 


\begin{abstract}
Peptidyl prolyl isomerases (PPIases) are proteins belonging to the immunophilin family and are characterised by their cis-trans isomerization activity at the X-Pro peptide bond, in addition to their tetratricopeptide repeat (TPR) domain, important for interaction with the molecular chaperone, Hsp90. Due to this unique structure these proteins are able to facilitate proteinprotein interactions which can impact significantly on a range of cellular processes such as cell signalling, differentiation, cell cycle progression, metabolic activity and apoptosis. Malfunction and/or dysregulation of most members of this class of proteins promotes cellular damage and tissue/organ failure, predisposing to ageing and age-related diseases. Many individual genes within the PPIase family are associated with several age-related diseases including cardiovascular diseases (CVDs), atherosclerosis, type II diabetes (T2D), chronic kidney disease $(\mathrm{CDK})$, neurodegeneration, cancer and age-related macular degeneration (AMD), in addition to the ageing process itself. This review will focus on the different roles of PPIases, and their therapeutic/biomarker potential in these age-related vascular diseases.
\end{abstract}

Keywords: PPIases, FKBPs, CypA, Pin1, aging, age-related diseases, vascular

\title{
Introduction
}

With an increase in life expectancy, the biggest challenge facing healthcare organisations is the management of age-related diseases. Age is the most strongly associated risk factor for diseases such as CVDs, cancer, T2D, CKD, neurodegenerative diseases, AMD and atherosclerosis ${ }^{1}$. Therefore finding a way of slowing down aging and delaying or preventing these age-related 
diseases will lead to longer life expectancy, healthy aging, and a better quality of life, thus reducing the financial burden on healthcare systems.

Twin studies have shown that for cohorts born about 100 years ago, approximately $25 \%$ of the variation in population lifespan is determined by genetic differences and that the genetic influence on lifespan and age-related diseases in particular, becomes relevant in those people who survive to 60 years $^{2}$. There have been major successes in the identification of new genetic variants involved in important age-related disorders including: cancer (in particular, prostate, breast and colon ${ }^{3-5} ; \mathrm{CVDs}^{6,7}$ and $\mathrm{CKD}^{8}$. However, many of these genetic variants, individually or combined, explain only a small component of the heritability of each disease. This modest contribution does not match with the high recurrence risks of age-related disorders in families. This apparent paradox may in part be explained by the contribution of low frequency variants, unrecognized single nucleotide polymorphism (SNP) epistasis, gene-environment interactions and epigenetic and gene expression changes. Epigenetic data is particularly valuable to help interpret genome wide association studies (GWAS) by adding biological/mechanistic information ${ }^{9,10}$. One of the major challenges over the next few decades will be to unravel the interactions between genetic variants and environmental factors. GWAS have shown that SNPs linked to multiple diseases are generally clustered on chromosome 6, in particular the Major Histocompatibility (MHC) locus within 6p21, in addition to the INK4/ARF (CDKN2a/b) tumour suppressor locus on chromosome 9p21.3. These SNPs accounted for almost a third of all the diseases analysed by GWAS ${ }^{11}$.

Aberrantly activated pathways in aging identified by association studies using long-lived cohorts include the insulin/insulin growth factor-1 (IGF-1), antioxidant, inflammatory, sirtuin, lipid metabolism, stress resistance and the mammalian target of rapamycin (mTOR) 
pathways $^{12-18}$. The main targets of the insulin and IGF-1 pathway are the FOXO transcription factors which have important roles in stress resistance, immunity and metabolism ${ }^{19,20}$. The sirtuin and mTOR pathways are nutrient-sensing pathways and these pathways are linked to longevity (high sirtuin and low mTOR levels) because of their ability to mediate the effects of nutrients and insulin. Since the mTOR pathway is a strongly implicated pathway, it represents a viable target for prevention of aging and age-related disease. Peptidyl prolyl isomerases (PPIases) also known as immunophillins, are a family of proteins that bind to rapamycinmTOR complexes and regulate the mTOR signaling pathway. These proteins therefore play a significant role in aging and age-related diseases ${ }^{21}$. Therefore, the focus of this review will be on the role of PPIase in aging and age-related diseases: CVDs, T2D, CKD, ND, AMD and cancer.

\section{PPIases}

The PPIase family are important determinants of ageing and disease. Many individual genes within the PPIase family are associated with several age-related diseases, in addition to the ageing process itself. Peptidyl prolyl isomerases (PPIases) are proteins belonging to the immunophilin family and are characterised by their cis-trans isomerization activity at the XPro peptide bond. The term immunophilin is derived from the ability of these proteins to bind immunosupressive drugs; cyclophilins (18 members, 17 genes) bind to cyclosporine A and FKBPs (FK506 binding proteins; 17 members, 17 genes) bind to the macrolide, FK506. A third subfamily, parvulins ( 3 members, 2 genes), contain the PPIase domain but do not bind immunosuppressive drugs ${ }^{22}$. Immunosuppression is generally associated with the smaller PPIase-complexes and the larger PPIases lack this effect but they contain the tetratricopeptide repeat (TPR) domain facilitating protein-protein interactions, significantly impacting many essential cellular processes. Therefore, aberrant function of these proteins can lead to tissue damage and predisposition to aging and age-related disease ${ }^{23,24}$. 


\section{Aging}

Aging, in terms of endothelial system changes, encompasses molecular and functional modifications such as shortening of telomeres, structurally and functionally altered endothelial cells, increased levels of vasoconstrictive, pro-inflammatory, proliferative and pro-coagulatory substances, reduced nitric oxide (NO) bioactivity and apoptosis ${ }^{25}$. These processes lead to an increase in blood pressure, a reduction in the glomerular filtration rate, atherosclerosis and therefore to age-related diseases.

More recently, cellular senescence and changes in immune system surveillance have been identified as being the most significant processes in aging due to their ability to activate proinflammatory pathways ${ }^{26-28}$. Other aberrant aging processes include protein aggregation, DNA damage, mitochondrial damage and accumulation of reactive oxygen species (ROS; Figure 1). More recently, research has focused on the role of aging stem cells on age-related diseases and the aging process itself. Due to their long lifespan, stem cells are more prone to cellular damage as they accumulate ROS, damaged proteins, DNA damage, epigenetic alterations and mitochondrial dysfunction ${ }^{29}$. All of these aberrant changes can lead to stem cell apoptosis, senescence, dysfunction and thus the inability of stem cells to orchestrate tissue regeneration and proliferation.

\section{The role of PPIases in aging}

The role of many individual PPIases in ageing has been studied. PPIases play a significant role by binding to and regulating the mTOR signalling pathway which has very well characterised roles in ageing and age-related diseases ${ }^{21}$. Furthermore, other PPIases such as CypA expression increases with ageing ${ }^{30-32}$ and suppression of CypB induces cellular senescence ${ }^{33}$ and its 
expression decreases in ageing rats $^{34}$. Likewise, $\mathrm{CypC}^{35,36}$; $\mathrm{CypD}^{37-39}$; $\mathrm{CypJ}^{40}$ have all demonstrated significant roles in animal models of ageing. FKBPL, a divergent member of the FKBP group of immunophilins, resides on the gene loci, 6p21.3 which is within a significant peak of age-related disease association ${ }^{11}$. Furthermore, it controls the levels of Sirt1 (unpublished data from our lab), a direct regulator of aging ${ }^{41}$. Importantly, Pin1 has the strongest link to ageing and is indeed a critical regulator of aging; Pin1-/- mice develop normally but show pronounced and premature aging, with reduced body size and bone density as well as atrophy of the skin, testis and breast ${ }^{42}$. Pin1 appears to control ageing by telomere shortening, via TRF1 phosphorylation and stability ${ }^{43}$, and also regulates senescence, via the p53-BTG2 pathway ${ }^{44}$.

\section{Cardiovascular diseases}

CVDs are the most common of all age-related diseases and are the leading cause of death in people over the age of sixty five $\mathrm{e}^{45}$. Because the aging process leads to an overproduction of pro-inflammatory, pro-coagulatory, vasoconstrictive and other related factors, it can lead to brittle heart walls, leaky/thickened heart valves and deterioration in the heart muscle, leading to poorer ability to pump blood efficiently around the body ${ }^{46}$. Therefore, these changes together with the age-related changes in the endothelial system mentioned above, can lead to atherosclerosis, angina, atrial fibrillation and orthotropic hypertension, potentially causing myocardial infarction and stroke ${ }^{47}$. The key signalling pathways associated with CVDs include the insulin and IGF-1, sirtuin and mTOR pathways. The IGF-1 pathway appears to have a protective mechanism against atherosclerosis in humans whereas in mice it led to an increase in life $\operatorname{span}^{48,49}$. The role of the sirtuin pathway in CVD is unclear due to a lack of consistency in the published data to suggest a strong role for this pathway in the development of CVDs; 
further research is therefore required ${ }^{50}$. On the other hand, the inhibition of the mTOR pathway, has demonstrated a role in longevity ${ }^{51}$; rapamycin can alleviate cardiac hypertrophy, T2D, adipogenesis and lipogenesis as such has a vital role in aging and $\operatorname{CVDs}^{47,52}$. Furthermore, the AMPK (AMP-protein activated kinase) signalling pathway, which negatively regulates mTOR, is also involved in CVDs; aberrant expression of AMPK in simple organisms, mice and humans has been implicated CVDs and aging ${ }^{53-55}$.

\section{The role of PPIases in CVDs}

FKBP12, a cytoplasmic FKBP, has a well-established interaction with the ryanodine receptor, RyRs, resulting in stabilisation of this channel. FKBP12 knockdown results in the opening of the RyRs channel and augments calcium release into a wide range of tissues ${ }^{56,57}$. Therefore, FKBP12 and FKBP12.6 have an important role in cardiac regulation and deficiency of these proteins contributes to the pathogenesis of hypertension. In murine models, FKBP12 knockout (KO) resulted in cardiac defects and altered ryanodine receptor function ${ }^{58-61}$. Therefore the treatment with FK506 and rapamycin may contribute to vascular dysfunction and hypertension by induced intracellular leakage of calcium ions in endothelial cells ${ }^{56,62}$. A novel antiarrhythmic compound, K201 (JTV- 519), which binds to FKBP12.6, thus stabilising RyRs channels and decreasing spontaneous calcium release, is currently in clinical trials ${ }^{63}$.

The most abundant member of the cyclophilin family, CypA, is excreted exogenously in response to inflammatory stimuli and able to increase ROS formation in endothelial cells, macrophages and vascular smooth muscle cells ${ }^{64-67}$. Therefore, CypA is a critical regulator of CVDs. In terms of vascular remodeling, CypA KO mice had significantly less thickened arteries when compared to the wild type (WT) mice and therefore are less likely to developed 
cardiac/vascular hypertrophy or myocardial ischaemia which can lead to myocardial injury ${ }^{68-}$ ${ }^{70}$. CypA's involvement in ROS generation and cardiac fibroblast proliferation and migration, renders it responsible for the development of cardiac hypertrophy, the basis of most of the CVDs $^{70,71}$. Interestingly serum levels of CypA were significantly higher in patients with acute coronary syndrome (ACS) when compared to healthy patients or patients with stable angina and the levels also correlated with the severity of ACS, potentially suggesting a role for CypA as a biomarker to predict the severity of $\mathrm{ACS}^{72}$. Furthermore, CypA has a well-established role in atherosclerosis and the mechanisms involve an increase in the uptake of low-density lipoproteins by the vessel wall due to CypA-mediated overexpression of the scavenger receptors, pro-inflammatory and endothelial cell activation of vascular cell adhesion molecule1 (VCAM-1) and a decrease of the endothelial nitric oxide synthase ${ }^{32}$

Another cyclophilin with a role in CVDs is CypD. Interestingly, it has a cytoprotective role during ischaemia-reperfusion injury as a regulator of the mitochondrial permeability transition pore (mPTP) complex formation ${ }^{73,74}$.

Finally, Pin1, the most extensively researched member of the parvulins subgroup (Pin1-3), has a significant role in cardiac hypertrophy. The loss of Pin1 attenuates cardiac hypertrophic responses following severe vasoconstriction by binding to Akt, mitogen activated protein kinase (MEK) and Raf-1; all essential components of the cardiac hypertrophy ${ }^{75}$.

\section{Type II diabetes}

T2D is an age-associated disease, more specifically related to accelerated aging. Most T2D patients are between the age of 65 and $74^{76}$. T2D is more prevalent in men within this age group and its incidence decreases above 75 years of age ${ }^{77}$. The pathophysiology of T2D is very 
closely linked to the dysfunction of pancreatic islet $\beta$-cells in addition to insulin resistance ${ }^{78}$. The pancreatic $\beta$-cells appear to lose their proliferative, secretory and regenerative function as part of aging, mainly due to cellular senescence ${ }^{79}$. Furthermore, the proliferative and apoptotic ability of the pancreatic $\beta$-cells seem to be the most apparent change in aging, obese and diabetic patients. These cells are also able to adjust their proliferative activity in metabolic distress e.g. in metabolic syndrome, by increasing their self-renewal capacity to manage the increasing demand for glucose utilisation ${ }^{79}$. Interestingly, the pancreatic $\beta$-cells display similar characteristics to stem cells such as low proliferative profile and a very long lifespan ${ }^{80}$. The proliferative and regenerative capacity of $\beta$-cells might be diminished with age as a result of accumulation of DNA damage during their long lifespan or it could be that these cells undergo senescence or apoptosis as a result of age-mediated shortening of the telomeres and/or activation of $\mathrm{p} 53$ and/or $\mathrm{p} 16^{\mathrm{INK} 4 \mathrm{~A} 81,82}$.

Aberrant molecular mechanisms involved in the induction of cellular senescence of the pancreatic $\beta$-cells include telomere shortening, cycle-dependent kinase inhibition by $\mathrm{p} 53$ and p16 ${ }^{\mathrm{INK} 4 \mathrm{~A}}$, which are also tumour suppressor genes ${ }^{83}$. Other pathways involved in the dysfunction of the pancreatic $\beta$-cells include the mTOR, sirtuin and IGF-1 pathways, also strongly associated with aging and other age-related diseases ${ }^{84}$. Furthermore, the negative regulator of the mTOR pathway, AMPK, has also been significantly implicated in the metabolic disorders and T2D; aberrant expression of AMPK in both mice and humans leads to insulin resistance ${ }^{54}$. 


\section{The role of PPIases in T2D}

The role of PPIases in T2D is still in its infancy however some interesting data has been recently reported to suggest important role for this group of proteins in T2D. For example, FKBP51 SNPs were found to be associated with T2D phenotypes in large population studies 85. Also, the change in FKBP51 gene expression was demonstrated in response to stress and diet therefore indicating a correlation between FKBP51 levels and higher food intake. Similarly, in mice, FKBP51 KO demonstrated a leaner phenotype when compared to the WT mice $^{86}$. Furthermore, in conjunction with insulin resistance markers, FKBP51, as a steroid hormone responsive and regulatory gene, demonstrated an increase in the expression, following dexamethasone exposure ${ }^{85}$.

Moreover, CypA has a role in T2D and vascular complications of T2D due to its proinflammatory role; patients with T2D were reported to have lower levels of CypA in high glucose-primed monocytes but high plasma levels of CypA when compared to healthy volunteers therefore suggesting a role for CypA as a biomarker of inflammation in T2D patients $^{87}$. Moreover the role of the PPIase, FKBPL, in the regulation of vascular/angiogenic functions implicates their potential in T2D-mediated vascular abnormalities (Yakkundi et al, unpublished data).

\section{Chronic Kidney Disease}

CKD is a leading cause of morbidity and mortality. Epidemiological studies demonstrated around $13 \%$ prevalence worldwide ${ }^{88,89}$. CKD arises from complete progressive destruction of nephrons resulting in the intact nephrons having to manage an increased load ${ }^{8,90}$. Despite research efforts, the pathophysiology of CKD is still not fully understood, although vascular, 
glomerular and tubular events are implicated in the disease $\mathrm{g}^{91,92}$. Furthermore, podocytes or visceral epithelial cells within the Bowman's capsule have a role in preventing protein escape into the urine and therefore the loss of podocytes has been associated with the development of diabetic neuropathy ${ }^{93,94}$. Aberrant mTOR activation is associated with this process and its inhibition by drugs such as rapamycin may be of a potential clinical benefit ${ }^{93,95}$. Similarly, the mTOR pathway is involved in aldosterone mediated signalling through the mineralocorticoid receptor within renal tubular epithelial cells of distal nephrons; important for the regulation of fluid homeostasis ${ }^{96,97}$. The activation of the mineralocorticoid receptor and its target genes including some of the PPIases, has been linked to tissue inflammation and fibrosis leading to $\mathrm{CKD}^{98-100}$.

\section{The role of PPIases in CKD}

In relation to $\mathrm{CKD}, \mathrm{FKBP} 12$ exhibits an inhibitory activity on calcium oxylate crystal deposition and may prevent nephrolithiasis ${ }^{101}$. Nephrolithiasis is often perceived as a relatively minor acute illness, but increasing evidence suggests that it can lead to $\mathrm{CKD}^{102-104}$. Furthermore, the pathogenesis of the condition shares overlapping features of many diseases of ageing such as hypertension, CVD and diabetes mellitus ${ }^{103,105,106}$. Recently, using a GWAS population analysis approach, FKBP51 has shown significant differences in DNA methylation in CKD patients ${ }^{107}$. Aldosterone plays a significant role in the development of CKD and evidence suggests that FKBP51 protein and mRNA expression are induced by aldosterone in the kidney and intestinal tissues ${ }^{108-110}$. On the other hand, CypA has a role in renal acidosis ${ }^{111}$, diabetic nephropathy ${ }^{112}$ and renal cell carcinoma ${ }^{113}$. Furthermore, Pin1 inhibition affects CKD associated with secondary parathyroidism ${ }^{114}$. 


\section{Neurodegeneration}

Neurodegeneration is the umbrella term for the progressive failure of neuronal networks leading to neuron death; many of these diseases share similarities at the sub-cellular level ${ }^{115,116}$. Ageing is the main risk factor for development of these diseases and the accumulation of atypical proteins, abnormal tangles and network dysfunction are classic hallmarks of these diseases $^{117}$.

Protein aggregation is a well-known feature of these diseases; however, the role of this process is not fully understood. Post-mortem examination of deceased brains have revealed that amyloid plaques in Alzheimer's disease and Lewy bodies in Parkinson's disease can be present even in asymptomatic patients and the extent of plaques present does not correlate to the severity of the disease at the time of death ${ }^{118}$.

Sustained activation of neuronal PI3K/Akt/mTOR signalling has been noted in early Alzheimer's disease ${ }^{119}$. In the temporal lobes of Alzheimer's patients, Akt activation leads to mTOR and tau phosphorylation and a decrease in cyclin-dependent kinase inhibitor $1^{120}$. Furthermore, the aberrant activation of the Akt pathway has been linked to disrupted clearance of $\mathrm{A} \beta$ and tau resulting in synaptic loss and cognitive decline ${ }^{119}$. Nevertheless, the cause of Alzheimer's disease is still largely unknown however the most prevalent genetic risk factor is the presence of $\varepsilon 4$ allele of the apolipoprotein E (APOE) and it is expressed in half of sporadic Alzheimer's disease cases ${ }^{121,122}$.

On the other hand, Parkinson's disease is the second most common neurodegenerative disease after Alzheimer's diseases. It is a degenerative disorder resulting from the death of the 
dopamine producing cells in the substantia nigra $(\mathrm{SN})^{123-125}$. Age-related mitochondrial dysfunction and alterations in protein degradation are more detrimental to the neurons in the SN than in any other regions of the brain ${ }^{126}$. The classic hallmark of this disease is the presence of the protein alpha synuclein which binds to ubiquitin in damaged cells forming oesinophilic cytoplasmic inclusions called Lewy bodies ${ }^{124,125,127}$. In Parkinson's disease, the $\mathrm{PI} 3 \mathrm{~K} / \mathrm{Akt} / \mathrm{mTOR}$ pathway is dysregulated in a different manner than in Alzheimer's disease. The dopaminergic neurons from Parkinson's patients display downregulation of phosphorylated Akt and supressed mTOR signalling resulting in neuronal death ${ }^{128}$. Furthermore, rapamycin, the inhibitor of mTOR, has a neuroprotective effect by protecting phosphorylated Akt at a critical site for cell survival ${ }^{129}$.

\section{The role of PPIases in neurodegeneration}

Calcium dysregulation contributes to unhealthy brain aging by reducing neural excitability and impairing memory. Disruption of FKBP12 in the hippocampal neurons destabilised calcium and in vivo FKBP12 knockdown is associated with an upregulation of RyR2 and mTOR protein expression $^{130}$. FKBP12 has been shown to bind to the intracellular domain of the amyloid precursor pathway and shift APP processing to the amyloidogenic pathway ${ }^{131,132}$. Moreover, the FKBP12 gene expression is downregulated in the hippocampus of aging rats and in early stage Alzheimer's patients ${ }^{133}$. When FK506 is used as an immunosuppressant agent, it appears to have neuroprotective effects ${ }^{134}$.

FKBP38 is a well-known inhibitor of apoptosis through a reduction in mitochondrial Bcl-2 135,136. Hsp90 can inhibit the apoptotic function of FKBP38 by interfering with the FKBP38/calmodulin/calcium complex which regulates the anti-apoptotic protein, Bcl-2 ${ }^{137}$. 
This property of FKBP38 protein has been exploited for the treatment of neurodegenerative diseases $^{136,138}$.

FKBP51's PPIase activity has a role in microtubule stabilisation through Hsp90-mediated dephoshorylation of tau ${ }^{139,140}$. On the other hand, FKBP52 is ubiquitously expressed at high levels and has been associated with microtubule destabilisation and tubulin depolymerisation ${ }^{140-142}$. FKBP51/FKBP52 bound to heat shock proteins may have a role in neurodegeneration by modulating protein folding and aggregation ${ }^{23}$. FKBP51 siRNA knockdown reduced tau levels in HeLa cells and FKBP51 overexpression increased levels of tau ${ }^{139}$. In addition, knockdown of Hsp90 also reduced levels ${ }^{143}$. In contrast, FKBP52 overexpression downregulated tau protein levels and knockdown resulted in increased tau binding to microtubules, resulting in longer projections ${ }^{131,142}$. Cao and Konsolaki proposed that the opposing effects of FKBP51 and FKBP52 could be due to the differences in PPIase activity as tau contains a high percentage of proline residues ${ }^{131}$. Furthermore, FKBP52 is upregulated after injury in regenerating neurons and Alzheimer's patients have a lower expression of FKBP52 in the temporal lobe and hippocampus ${ }^{131}$. FKBP52 is involved in the regulation of intracellular copper and this may cause FKBP52 to have an effect on A $\beta$ levels ${ }^{144-146}$. Furthermore, Conejero-Goldberg and colleagues demonstrated that FKBPL was one of the key genes differentially expressed in the brain tissue, where it appeared to act in a protective role, in young individuals at high risk of Alzheimers disease preselected by the APO4 signature ${ }^{147}$.

The role of CypA in Alzheimer's disease has also been reported, possibly due to its ability to activate pro-inflammatory pathways, NF-KB and MMP-9; these pathways in brain capillary pericytes regulate the release of neurotoxins. This whole process is initiated by APO4 within astrocytes $^{148}$. CypD's involvement in the mPTP complex has also found application in 
Alzheimer's disease due to recent reports which suggest that $\mathrm{A} \beta$ proteins influence mPTP formation when in a complex with $\mathrm{CypD}^{149}$. Conversely, the loss of Pin1 expression is correlated with Alzheimer's disease and neurodegeneration due to Pin1's important role in the stabilisation and regulation of tau and $A \beta$ proteins $^{42}$. Tau protein hyperphosphorylates in the absence of Pin1 leading to its dysfunction and inability to regulate microtubule stabilisation in the neurons ${ }^{150}$.

\section{Age-related macular degeneration}

Age-related macular degeneration (AMD) is a leading cause of blindness worldwide and old age is the major risk factor with an incidence of $10 \%$ in individuals over 80 years of age ${ }^{151,152}$. It results from degeneration of the macular region of the retina, a central part of the retina and AMD susceptibility is increased by age, environmental (e.g. smoking) and genetic factors ${ }^{152,153}$. Many different genetic factors have been implicated in AMD including SNPs within some of the proteins involved in the mTOR pathway ${ }^{154}$.

\section{The role of PPIases in AMD}

In AMD GWAS the presence of SNPs on chromosome p6.21 in the FKBPL region was demonstrated therefore suggesting a potential role for FKBPL as an AMD susceptible gene ${ }^{155}$. This study was carried out using two cohorts of advanced AMD patients against matched controls to validate the findings and it also indicated Notch4 as a potential AMD susceptible gene. Our own lab has generated data to suggest that in addition to the well-established FKBPL's regulatory role of the CD44 pathway, it is also involved in the regulation of the Notch pathway (unpublished data).

\section{Cancer}


Cancer is defined as the development of 'abnormal cells' due to genetic and epigenetic changes in oncogenes and tumour suppressors ${ }^{156}$. These genetic changes can be inherited, acquired by various DNA damaging agents or certain types of viruses. There are a few theories of carcinogenesis nevertheless it is considered a multistep process involving genetic instabilities which drive normal cells to malignant, cancer cells. More recently, a subgroup of cancer cells, termed cancer stem cells (CSCs) or tumour initiating cells, have been characterised as a group of cells carrying the oncogenic and tumour suppressor mutated genes responsible for tumour initiation and progression ${ }^{157}$.

Numerous cellular and intracellular pathways regulating tumourigenesis have been implicated in the development of cancer. A pathway readily activated as a result of a loss of the main tumour suppressor genes, p53 or PTEN, is PI3K-Akt survival pathway ${ }^{158}$. This pathway regulates the mTOR pathway and once the mTOR pathway is activated, negative feedback results in PI3K inhibition. Therefore when the mTOR pathway is inhibited by rapamycin, for example, the mutated or lost negative feedback loops, commonly present within cancer cells, activate the PI3K-Akt pathway instead of inhibiting it, thereby preventing the anti-proliferative effect of the mTOR pathway inhibition ${ }^{159,160}$.

\section{The role of PPIases in cancer}

The roles of PPIases in cancer have been studied extensively. Some members appear to have oncogenic activity whilst others behave as tumour suppressors. FKBP12 is overexpressed in benign and malignant endothelial-lined vasculature and as a natural ligand of TGF- $\beta$ receptor I is subsequently involved in regulating cancer invasion ${ }^{161}$. Knockdown of FKBP12 results in the cell cycle arrest at the G1 phase by downregulation of TGF- $\beta$ signalling ${ }^{162}$. Furthermore, FKBP12 activates TGF- $\beta$ receptor I kinase thus triggering apoptosis by a mitochondrial 
dependent pathway ${ }^{163}$. In addition, it is a regulator of H-Ras trafficking by promoting depalmitoylation through its PPIase activity ${ }^{164}$. Disruption of the interaction between FKBP12 and calcineurin signalling leads to potent anti-angiogenic effects and tumour growth inhibition in breast cancer ${ }^{165}$.

FKBP38 is capable of potentiating the biological function of Bcl-2 protein leading to tumourigenesis and chemoresistance ${ }^{136,166}$. Furthermore, Bcl-2 overexpression has been associated with the cancer stem cell phenotype and it may contribute to chemoresistance within these cells ${ }^{167}$.

FKBP51 expression is hormone related and its overexpression has been associated with leukaemia, breast, prostate and brain tumours ${ }^{168,169}$. FKBP51 is a negative regulator of the Akt pathway and regulates cell response to chemotherapy ${ }^{170}$. Furthermore, FKBP51 regulates the NF-KB pathway which is implicated in apoptosis and radioresistance in melanoma cells ${ }^{171,172}$. More recently, the role of FKBP51 in stemness and metastasis in melanoma was demonstrated by Romano et al (2013), where FKBP51 was overexpressed and associated with tumour aggressiveness and treatment resistance by stimulation of the EMT process, migration and invasion via the TGF- $\beta$ pathway ${ }^{173}$. Furthermore, androgens upregulate FKBP51 by initiating direct binding between FKBP51 and the androgen receptor $(A R)^{174}$. In murine xenograft models it was demonstrated that FKBP51 is a direct regulator of cell growth and may have a role in the highly invasive androgen-independent type of prostate cancer ${ }^{174,175}$. The FKBP51/AR interaction is mediated by Hsp90, and Hsp90 inhibitors such as geldanamycin are currently in clinical trials in a variety of cancers ${ }^{176,177}$. In pancreatic cancer, FKBP51 acts as a scaffolding protein to the phosphatase PHLPP resulting in upregulation of the pro-survival Akt pathway and reducing sensitivity to the chemotherapy ${ }^{170}$. Conversely, in colorectal 
adenocarcinoma, FKBP51 suppresses proliferation through its action on the glucocorticoid receptor $^{178}$

Less is known about the role of FKBP52 in cancer, although its inhibition has been shown to block androgen receptor dependent gene expression and prostate cancer cell proliferation ${ }^{179}$. Moreover, FKBP52 is highly expressed in hormone-positive cancers such as oestrogen receptor positive $(\mathrm{ER}+)$ breast cancer; its expression in pre-invasive breast cancer was also much higher than the surrounding normal breast tissue speculating its role in breast cancer initiation ${ }^{180,181}$. FKBP52 is not a functional regulator of the oestrogen receptor but interestingly, it is upregulated in breast tumours and FKBP52 gene methylation only occurs in ER negative breast cancer cells $^{182}$. Furthermore, FKBP52 auto-antibodies may be a useful biomarker for early diagnosis and monitoring of breast cancer ${ }^{183}$.

FKBP65 is highly expressed in early benign lesions in the colon, compared to normal mucosa ${ }^{184}$. This suggests that FKBP65 may be involved in colorectal carcinogenesis and could be a novel colorectal biomarker ${ }^{183}$. FKBP65 is strongly expressed in normal and benign ovarian epithelium but a low expression in high grade serous carcinoma (HGSC) is probably due to frequent loss of chromosome 17 in $\mathrm{HGSC}^{185,186}$. This indicates a tumour suppressor function for FKBP65 in ovarian carcinomas.

FKBPL has a well-established role in cancer and whilst most FKBPs are positive regulators of cancer growth, FKBPL, as a divergent member of this family, is not. FKBPL acts as a cochaperone protein in a complex with Hsp90 where it has a regulatory role in steroid receptor signalling $(\mathrm{ER})^{187} ;(\mathrm{AR})^{188} ;(\mathrm{GR})^{189}$. Due to this negative regulatory effect of the steroid receptors, overexpression of FKBPL demonstrated inhibition of cancer cell growth in ER+ 
breast cancers ${ }^{187}$; in lymphoma this inhibitory effect was associated with a FKBPL, Hsp90 and p21 complex ${ }^{190}$. Furthermore, in ER+ breast cancer, high FKBPL levels improved the response to endocrine therapy such as tamoxifen and fulvestrant and sensitised cells to oestrogen deprivation and was also prognostic for survival ${ }^{187}$. Other relevant roles of endogenous FKBPL in a complex with Hsp90, p21 and GTSE-1 (G2 and S phase expressed protein 1) include, chemo- and radiosensitivity via regulation of the cell cycle protein, $\mathrm{p} 21^{\mathrm{CIP} 1 / \mathrm{WAF} 1}$, and a reduction in the DNA repair ${ }^{191,192}$. All of these FKBPL-related roles are associated with intracellular FKBPL however more recently, an extracellular role for FKBPL was identified. This extracellular role was associated with a potent anti-angiogenic and anti-CSC function which is initiated following binding of FKBPL to the CD44 cell surface receptor ${ }^{193-195}$. The region responsible for this interaction is the $\mathrm{N}$-terminal region of FKBPL, which is unique and not homologous to other FKBPs. Based on this anti-angiogenic domain, a clinical candidate 23-amino acid therapeutic peptide, ALM201, was designed in collaboration with Almac Discovery which will enter clinical trials this year ${ }^{196}$. Therefore, FKBPL as a divergent member of the FKBPs appears to be involved in similar biological processes in cancer to other FKBPs whilst exerting an opposite function as an anti-cancer or tumour suppressor protein.

In cancer CypA is significantly upregulated and as such is involved in malignant transformation, tumour growth, invasion, metastasis and the inhibition of apoptosis ${ }^{197-200}$. This is not surprising considering CypA has a role in the stimulation of endothelial cell migration which is important for tumour growth and invasion ${ }^{69}$. Furthermore, CypA is transcriptionally regulated by $\mathrm{p} 53$ and hypoxia inducible factor- $1 \alpha(\mathrm{HIF}-1 \alpha)$ both factors commonly mutated in cancer $^{201}$. CypA seems also responsible for paclitaxel-induced resistance in endometrial cancer and overexpression of CypA can reduce cisplatin and hypoxia-induced apoptosis ${ }^{202,203}$. On the other hand, CypA has also an important role in the cytokinesis where it relocalises from its 
original position, in the centrosome, to the midbody; the loss of CypD leads to defective cytokinesis which can increase genomic instability associated with cancer ${ }^{204}$. Other members of the Cyp family group CypB, CypC and CypD in addition to CypA also appear to be upregulated at the transcriptional levels in various cancers ${ }^{201}$. CypB and CypC are associated with the ER and as such form various complexes with other oestrogen-related chaperones and CypB, in particular, protects cells from oestrogen receptor stress-induced death ${ }^{205,206}$. However, overexpression of $\mathrm{CypB}$ has been linked to tumour progression because it regulated various hormone receptors and their downstream targets ${ }^{207}$. Also, CypB could be a useful target for delivery of anti-cancer vaccines due to its two antigenic epitopes identifiable by the cytotoxic T-lymphocytes ${ }^{208}$. Moreover, Cyp40 mRNA levels were reported to be high in response to stress in breast and prostate cancer cell lines when compared to normal breast and prostate cell lines ${ }^{209}$. CypD, as mentioned above, is involved in mPTP complex formation and as such has a role in the resistance to $\mathrm{mPTP}$-induced cancer cell death. This is mediated by other co-chaperone proteins such as Hsp90, TRAP and Hsp60 highly expressed in cancer cell mitochondria and their ability to inhibit CypD therefore disabling mPTP formation and its apoptotic effects ${ }^{210}$. Also, mitochondrial CypD knockdown is associated with STAT3 activation which leads to an increase in cell proliferation, by accelerating entry into S-phase, and migration, via the chemokine network, CXCL12-CXCR $4^{211}$. Both of these phenotypes are closely linked to cancer progression and metastasis. Furthermore, $\mathrm{CypD}^{-/-}$mice exhibit similar phenotype to Pin $1^{-/-}$mice in terms of abnormalities observed in retina and breast development which could potentially lead to malignant transformations in these organs ${ }^{212,213}$. Also, transcriptional and posttranslational regulation of CypD by Pin 1 was demonstrated in the more recent study therefore explaining the phenotypical similarities observed in $\mathrm{CypD}^{-/-}$and $\mathrm{Pin}^{-/-}$ mice ${ }^{213}$. 
Pin 1 has been researched extensively for its oncogenic role in cancer $^{214}$. Pin1 is also important for tumourigenesis and for the regulation of CSCs via the Notch pathway ${ }^{215}$. In fact, deletion of Pin1 in mice prevented oncogenic activation of Neu and Ha-Ras which abrogated breast cancer $^{216}$. In p53-KO mice Pin1 deletion was able to completely abrogate tumour development but had adverse effects including thymic hyperplasia mediated via the Notch pathways ${ }^{217}$. Nevertheless, Pin1 does not affect the p53 tumour suppressor activity ${ }^{218}$. Other cancerassociated processes that Pin 1 affects include regulation of cell cycle, DNA damage, cell signaling, transcription and splicing ${ }^{219}$. In terms of cell-cycle regulation, Pin1 also has a role in cytokinesis by binding to the crucial centrosome protein, Cep55, which further explains its role in tumourigenesis ${ }^{220}$

\section{PPIases as targets to prevent ageing or to treat age-related diseases}

An advantage of characterising this gene family is that they are targetable and various drugs targeting these proteins have been reported, including FK506, sirolimus/rapamycin, cyclosporine, and tacrolimus ${ }^{22}$. Ligands of these proteins, although first approved as immunosuppressive agents, for the prevention of allograft rejection, are effective against agerelated diseases. Several FKBP-binding macrocyclic drugs, everolimus, zotarolimus and temsirolius are in phase III trials as targets for cell proliferation, immunosuppression and anticancer effects $^{23}$. Recent evidence has also identified rapamycin/sirolimus as being the first drug to extend lifespan in a range of species from yeast to mammals ${ }^{221,222}$, highlighting the potential for drug targeting within this gene family to alleviate the ageing process. Importantly, recent studies have also shown that FK506-binding proteins can modulate Akt-mTOR signalling in the absence of rapamycin ${ }^{21}$. 
One of the problems associated with PPIase inhibitors however, is their off-target effects, particularly and not surprisingly, immunosuppression. However, more recently there has been a concerted effort to generate compounds that lack immunosuppressive activity, with various levels of success. Examples of such compounds include non-immunosuppressive analogues of cyclosporine A which may have applications in multiple therapeutic areas e.g. Alisporivir (Debio 025) and NIM811223,224. Similarly, the development of cell impermeable, nonimmunosuppressive analogues of cyclosporine A has permitted the inhibition of extracellular CypA in mouse models of inflammation ${ }^{225}$. Such drugs have huge potential in the treatment of ageing disease in which CypA is involved.

The novel FKBPL-based therapeutic, ALM201, unlike other PPIases, appears to be protective of age-related diseases ${ }^{147,154,187,193,194,196}$; ALM201 is a peptide mimetic of FKBPL and could essentially correct a deficiency in FKBPL in a number of diseases. It has already completed preclinical evaluation for imminent phase I/II clinical trials in cancer patients ${ }^{196}$; our unpublished data also suggests that it has activity against a number of other inflammatory conditions.

\section{Conclusion}

In conclusion, there are many different significant roles of PPIases in age-related processes and diseases as indicated above (Table 1; Figure 2). Even though these proteins belong to the same family group, their roles are quite diverse and in some instances opposite. Therefore, it is of a paramount importance to elucidate the mechanisms involved in the interactive regulation of this gene family. This may allow the development of a genetic signature which could stratify patients with higher predisposition to unhealthy aging therefore enabling early treatment to 
delay or prevent these age-related vascular diseases and their complications. Members of this family of proteins are therefore excellent targets for interventions as well as biomarkers of aging and age-related diseases. Because many of the PPIase family members are secreted ${ }^{226,227}$, monitoring them within ageing populations will be minimally invasive and therefore practical for routine clinical use or home test.

\section{References}

(1) Blagosklonny, M. V. Aging: ROS or TOR. Cell Cycle 2008, 7, 3344-3354.

(2) Karasik, D.; Demissie, S.; Cupples, L. A.; Kiel, D. P. Disentangling the Genetic Determinants of Human Aging: Biological Age as an Alternative to the Use of Survival Measures. J. Gerontol. A. Biol. Sci. Med. Sci. 2005, 60, 574-587. 
(3) Yu, D.-H.; Waterland, R. A.; Zhang, P.; Schady, D.; Chen, M.-H.; Guan, Y.; Gadkari, M.; Shen, L. Targeted p16(Ink4a) Epimutation Causes Tumorigenesis and Reduces Survival in Mice. J. Clin. Invest. 2014, 124, 3708-3712.

(4) Hicks, C.; Koganti, T.; Giri, S.; Tekere, M.; Ramani, R.; Sitthi-Amorn, J.; Vijayakumar, S. Integrative Genomic Analysis for the Discovery of Biomarkers in Prostate Cancer. Biomark. Insights 2014, 9, 39-51.

(5) Whiffin, N.; Hosking, F. J.; Farrington, S. M.; Palles, C.; Dobbins, S. E.; Zgaga, L.; Lloyd, A.; Kinnersley, B.; Gorman, M.; Tenesa, A.; Broderick, P.; Wang, Y.; Barclay, E.; Hayward, C.; Martin, L.; Buchanan, D. D.; Win, A. K.; Hopper, J.; Jenkins, M.; Lindor, N. M.; Newcomb, P. A.; Gallinger, S.; Conti, D.; Schumacher, F.; Casey, G.; Liu, T.; Campbell, H.; Lindblom, A.; Houlston, R. S.; Tomlinson, I. P.; Dunlop, M. G. Identification of Susceptibility Loci for Colorectal Cancer in a Genome-Wide MetaAnalysis. Hum. Mol. Genet. 2014, 23, 4729-4737.

(6) Marti-Soler, H.; Gubelmann, C.; Aeschbacher, S.; Alves, L.; Bobak, M.; Bongard, V.; Clays, E.; de Gaetano, G.; Di Castelnuovo, A.; Elosua, R.; Ferrieres, J.; Guessous, I.; Igland, J.; Jørgensen, T.; Nikitin, Y.; O’Doherty, M. G.; Palmieri, L.; Ramos, R.; Simons, J.; Sulo, G.; Vanuzzo, D.; Vila, J.; Barros, H.; Borglykke, A.; Conen, D.; De Bacquer, D.; Donfrancesco, C.; Gaspoz, J.-M.; Giampaoli, S.; Giles, G. G.; Iacoviello, L.; Kee, F.; Kubinova, R.; Malyutina, S.; Marrugat, J.; Prescott, E.; Ruidavets, J. B.; Scragg, R.; Simons, L. A.; Tamosiunas, A.; Tell, G. S.; Vollenweider, P.; MarquesVidal, P. Seasonality of Cardiovascular Risk Factors: An Analysis Including over 230 000 Participants in 15 Countries. Heart 2014, 100, 1517-1523.

(7) Blankenberg, S.; Zeller, T.; Saarela, O.; Havulinna, A. S.; Kee, F.; Tunstall-Pedoe, H.; Kuulasmaa, K.; Yarnell, J.; Schnabel, R. B.; Wild, P. S.; Münzel, T. F.; Lackner, K. J.; Tiret, L.; Evans, A.; Salomaa, V. Contribution of 30 Biomarkers to 10-Year Cardiovascular Risk Estimation in 2 Population Cohorts: The MONICA, Risk, Genetics, Archiving, and Monograph (MORGAM) Biomarker Project. Circulation 2010, 121, 2388-2397.

(8) Smyth, L. J.; Duffy, S.; Maxwell, A. P.; McKnight, A. J. Genetic and Epigenetic Factors Influencing Chronic Kidney Disease. Am. J. Physiol. Renal Physiol. 2014, 307, F757F776.

(9) Bernstein, H. S.; Hyun, W. C. Strategies for Enrichment and Selection of Stem CellDerived Tissue Precursors. Stem Cell Res. Ther. 2012, 3, 17.

(10) Shenker, N. S.; Polidoro, S.; van Veldhoven, K.; Sacerdote, C.; Ricceri, F.; Birrell, M. A.; Belvisi, M. G.; Brown, R.; Vineis, P.; Flanagan, J. M. Epigenome-Wide Association Study in the European Prospective Investigation into Cancer and Nutrition (EPIC-Turin) Identifies Novel Genetic Loci Associated with Smoking. Hum. Mol. Genet. 2013, 22, 843-851.

(11) Jeck, W. R.; Siebold, A. P.; Sharpless, N. E. Review: A Meta-Analysis of GWAS and Age-Associated Diseases. Aging Cell 2012, 11, 727-731. 
(12) Gerdes, L. U.; Jeune, B.; Ranberg, K. A.; Nybo, H.; Vaupel, J. W. Estimation of Apolipoprotein E Genotype-Specific Relative Mortality Risks from the Distribution of Genotypes in Centenarians and Middle-Aged Men: Apolipoprotein E Gene Is a "Frailty Gene," Not a "Longevity Gene". Genet. Epidemiol. 2000, 19, 202-210.

(13) Rose, G.; Dato, S.; Altomare, K.; Bellizzi, D.; Garasto, S.; Greco, V.; Passarino, G.; Feraco, E.; Mari, V.; Barbi, C.; BonaFe, M.; Franceschi, C.; Tan, Q.; Boiko, S.; Yashin, A. I.; De Benedictis, G. Variability of the SIRT3 Gene, Human Silent Information Regulator Sir2 Homologue, and Survivorship in the Elderly. Exp. Gerontol. 2003, 38, 1065-1070.

(14) Bonafè, M.; Olivieri, F. Genetic Polymorphism in Long-Lived People: Cues for the Presence of an insulin/IGF-Pathway-Dependent Network Affecting Human Longevity. Mol. Cell. Endocrinol. 2009, 299, 118-123.

(15) Chung, W.-H.; Dao, R.-L.; Chen, L.-K.; Hung, S.-I. The Role of Genetic Variants in Human Longevity. Ageing Res. Rev. 2010, 9 Suppl 1, S67-78.

(16) Soerensen, M.; Dato, S.; Christensen, K.; McGue, M.; Stevnsner, T.; Bohr, V. A.; Christiansen, L. Replication of an Association of Variation in the FOXO3A Gene with Human Longevity Using Both Case-Control and Longitudinal Data. Aging Cell 2010, 9, $1010-1017$.

(17) Slagboom, P. E.; Beekman, M.; Passtoors, W. M.; Deelen, J.; Vaarhorst, A. A. M.; Boer, J. M.; van den Akker, E. B.; van Heemst, D.; de Craen, A. J. M.; Maier, A. B.; Rozing, M.; Mooijaart, S. P.; Heijmans, B. T.; Westendorp, R. G. J. Genomics of Human Longevity. Philos. Trans. R. Soc. Lond. B. Biol. Sci. 2011, 366, 35-42.

(18) Montesanto, A.; Dato, S.; Bellizzi, D.; Rose, G.; Passarino, G. Epidemiological, Genetic and Epigenetic Aspects of the Research on Healthy Ageing and Longevity. Immun. Ageing 2012, 9, 6.

(19) Murphy, C. T.; Mccarroll, S. A.; Bargmann, C. I.; Fraser, A.; Kamath, R. S.; Ahringer, J.; Li, H.; Kenyon, C. Genes That Act Downstream of DAF-16 to Influence the Lifespan of Caenorhabditis Elegans. 2003, 277-284.

(20) McElwee, J.; Bubb, K.; Thomas, J. H. Transcriptional Outputs of the Caenorhabditis Elegans Forkhead Protein DAF-16. Aging Cell 2003, 2, 111-121.

(21) Hausch, F.; Kozany, C.; Theodoropoulou, M.; Fabian, A.-K. FKBPs and the Akt/mTOR Pathway. Cell Cycle 2013, 12, 2366-2370.

(22) Erlejman, A. G.; Lagadari, M.; Galigniana, M. D. Hsp90-Binding Immunophilins as a Potential New Platform for Drug Treatment. Future Med. Chem. 2013, 5, 591-607.

(23) Galat, A. Functional Diversity and Pharmacological Profiles of the FKBPs and Their Complexes with Small Natural Ligands. Cell. Mol. Life Sci. 2013, 70, 3243-3275.

(24) Cox, M. B.; Smith, D. F. Hapter 2. 2007. 
(25) Barton, M. Prevention and Endothelial Therapy of Coronary Artery Disease. Curr. Opin. Pharmacol. 2013, 13, 226-241.

(26) Michaud, M.; Balardy, L.; Moulis, G.; Gaudin, C.; Peyrot, C.; Vellas, B.; Cesari, M.; Nourhashemi, F. Proinflammatory Cytokines, Aging, and Age-Related Diseases. J. Am. Med. Dir. Assoc. 2013, 14, 877-882.

(27) Lakatta, E. G.; Levy, D. Arterial and Cardiac Aging: Major Shareholders in Cardiovascular Disease Enterprises: Part I: Aging Arteries: A "Set up" for Vascular Disease. Circulation 2003, 107, 139-146.

(28) Howcroft, T. K.; Campisi, J.; Louis, G. B.; Smith, M. T.; Wise, B.; Wyss-Coray, T.; Augustine, A. D.; McElhaney, J. E.; Kohanski, R.; Sierra, F. The Role of Inflammation in Age-Related Disease. Aging (Albany. NY). 2013, 5, 84-93.

(29) Oh, J. Y.; Ko, J. H.; Lee, H. J.; Yu, J. M.; Choi, H.; Kim, M. K.; Wee, W. R.; Prockop, D. J. Mesenchymal Stem/stromal Cells Inhibit the NLRP3 Inflammasome by Decreasing Mitochondrial Reactive Oxygen Species. Stem Cells 2014, 32, 1553-1563.

(30) Bane, F. T.; Bannon, J. H.; Pennington, S. R.; Campiani, G.; Campaini, G.; Williams, D. C.; Zisterer, D. M.; Mc Gee, M. M. The Microtubule-Targeting Agents, PBOX-6 [pyrrolobenzoxazepine 7-[(dimethylcarbamoyl)oxy]-6-(2-Naphthyl)pyrrolo-[2,1-D] (1,5)-Benzoxazepine] and Paclitaxel, Induce Nucleocytoplasmic Redistribution of the Peptidyl-Prolyl Isomerases, Cyclophilin A and pin1,. J. Pharmacol. Exp. Ther. 2009, 329, 38-47.

(31) Li, J.; Xie, H.; Yi, M.; Peng, L.; Lei, D.; Chen, X.; Jian, D. Expression of Cyclophilin A and CD147 during Skin Aging. Zhong Nan Da Xue Xue Bao. Yi Xue Ban 2011, 36, 203-211.

(32) Nigro, P.; Satoh, K.; O’Dell, M. R.; Soe, N. N.; Cui, Z.; Mohan, A.; Abe, J.; Alexis, J. D.; Sparks, J. D.; Berk, B. C. Cyclophilin A Is an Inflammatory Mediator That Promotes Atherosclerosis in Apolipoprotein E-Deficient Mice. J. Exp. Med. 2011, 208, 53-66.

(33) Liao, X.; Siu, M. K. Y.; Au, C. W. H.; Wong, E. S. Y.; Chan, H. Y.; Ip, P. P. C.; Ngan, H. Y. S.; Cheung, A. N. Y. Aberrant Activation of Hedgehog Signaling Pathway in Ovarian Cancers: Effect on Prognosis, Cell Invasion and Differentiation. Carcinogenesis 2009, 30, 131-140.

(34) Lam, Y. W.; Tam, N. N. C.; Evans, J. E.; Green, K. M.; Zhang, X.; Ho, S.-M. Differential Proteomics in the Aging Noble Rat Ventral Prostate. Proteomics 2008, 8, 2750-2763.

(35) Torlakovic, E. E.; Keeler, V.; Wang, C.; Lim, H. J.; Lining, L. A.; Laferté, S. Cyclophilin C-Associated Protein (CyCAP) Knock-out Mice Spontaneously Develop Colonic Mucosal Hyperplasia and Exaggerated Tumorigenesis after Treatment with Carcinogen Azoxymethane. BMC Cancer 2009, 9, 251.

(36) Shimizu, T.; Imai, H.; Seki, K.; Tomizawa, S.; Nakamura, M.; Honda, F.; Kawahara, N.; Saito, N. Cyclophilin C-Associated Protein and Cyclophilin C mRNA Are 
Upregulated in Penumbral Neurons and Microglia after Focal Cerebral Ischemia. $J$. Cereb. Blood Flow Metab. 2005, 25, 325-337.

(37) Elrod, J. W.; Wong, R.; Mishra, S.; Vagnozzi, R. J.; Sakthievel, B.; Goonasekera, S. A.; Karch, J.; Gabel, S.; Farber, J.; Force, T.; Brown, J. H.; Murphy, E.; Molkentin, J. D. Cyclophilin D Controls Mitochondrial Pore-Dependent $\mathrm{Ca}(2+)$ Exchange, Metabolic Flexibility, and Propensity for Heart Failure in Mice. J. Clin. Invest. 2010, 120, 36803687.

(38) Hafner, A. V; Dai, J.; Gomes, A. P.; Xiao, C.-Y.; Palmeira, C. M.; Rosenzweig, A.; Sinclair, D. A. Regulation of the mPTP by SIRT3-Mediated Deacetylation of CypD at Lysine 166 Suppresses Age-Related Cardiac Hypertrophy. Aging (Albany. NY). 2010, 2, 914-923.

(39) Lu, J.-H.; Shi, Z.-F.; Xu, H. The Mitochondrial Cyclophilin D/p53 Complexation Mediates Doxorubicin-Induced Non-Apoptotic Death of A549 Lung Cancer Cells. Mol. Cell. Biochem. 2014, 389, 17-24.

(40) Huo, D.-H.; Yi, L.-N.; Yang, J. Interaction with Ppil3 Leads to the Cytoplasmic Localization of Apoptin in Tumor Cells. Biochem. Biophys. Res. Commun. 2008, 372, $14-18$.

(41) Blagosklonny, M. V. TOR-Driven Aging: Speeding Car without Brakes. Cell Cycle 2009, 8, 4055-4059.

(42) Lee, T. H.; Pastorino, L.; Lu, K. P. Peptidyl-Prolyl Cis-Trans Isomerase Pin1 in Ageing, Cancer and Alzheimer Disease. Expert Rev. Mol. Med. 2011, 13, e21.

(43) Lee, T. H.; Tun-Kyi, A.; Shi, R.; Lim, J.; Soohoo, C.; Finn, G.; Balastik, M.; Pastorino, L.; Wulf, G.; Zhou, X. Z.; Lu, K. P. Essential Role of Pin1 in the Regulation of TRF1 Stability and Telomere Maintenance. Nat. Cell Biol. 2009, 11, 97-105.

(44) Wheaton, K.; Muir, J.; Ma, W.; Benchimol, S. BTG2 Antagonizes Pin1 in Response to Mitogens and Telomere Disruption during Replicative Senescence. Aging Cell 2010, 9, 747-760.

(45) Lozano, R.; Naghavi, M.; Foreman, K.; Lim, S.; Shibuya, K.; Aboyans, V.; Abraham, J.; Adair, T.; Aggarwal, R.; Ahn, S. Y.; Alvarado, M.; Anderson, H. R.; Anderson, L. M.; Andrews, K. G.; Atkinson, C.; Baddour, L. M.; Barker-Collo, S.; Bartels, D. H.; Bell, M. L.; Benjamin, E. J.; Bennett, D.; Bhalla, K.; Bikbov, B.; Bin Abdulhak, A.; Birbeck, G.; Blyth, F.; Bolliger, I.; Boufous, S.; Bucello, C.; Burch, M.; Burney, P.; Carapetis, J.; Chen, H.; Chou, D.; Chugh, S. S.; Coffeng, L. E.; Colan, S. D.; Colquhoun, S.; Colson, K. E.; Condon, J.; Connor, M. D.; Cooper, L. T.; Corriere, M.; Cortinovis, M.; de Vaccaro, K. C.; Couser, W.; Cowie, B. C.; Criqui, M. H.; Cross, M.; Dabhadkar, K. C.; Dahodwala, N.; De Leo, D.; Degenhardt, L.; Delossantos, A.; Denenberg, J.; Des Jarlais, D. C.; Dharmaratne, S. D.; Dorsey, E. R.; Driscoll, T.; Duber, H.; Ebel, B.; Erwin, P. J.; Espindola, P.; Ezzati, M.; Feigin, V.; Flaxman, A. D.; Forouzanfar, M. H.; Fowkes, F. G. R.; Franklin, R.; Fransen, M.; Freeman, M. K.; Gabriel, S. E.; Gakidou, E.; Gaspari, F.; Gillum, R. F.; Gonzalez-Medina, D.; Halasa, Y. A.; Haring, D.; Harrison, J. E.; Havmoeller, R.; Hay, R. J.; Hoen, B.; Hotez, P. J.; Hoy, D.; Jacobsen, 
K. H.; James, S. L.; Jasrasaria, R.; Jayaraman, S.; Johns, N.; Karthikeyan, G.; Kassebaum, N.; Keren, A.; Khoo, J.-P.; Knowlton, L. M.; Kobusingye, O.; Koranteng, A.; Krishnamurthi, R.; Lipnick, M.; Lipshultz, S. E.; Ohno, S. L.; Mabweijano, J.; MacIntyre, M. F.; Mallinger, L.; March, L.; Marks, G. B.; Marks, R.; Matsumori, A.; Matzopoulos, R.; Mayosi, B. M.; McAnulty, J. H.; McDermott, M. M.; McGrath, J.; Mensah, G. A.; Merriman, T. R.; Michaud, C.; Miller, M.; Miller, T. R.; Mock, C.; Mocumbi, A. O.; Mokdad, A. A.; Moran, A.; Mulholland, K.; Nair, M. N.; Naldi, L.; Narayan, K. M. V.; Nasseri, K.; Norman, P.; O’Donnell, M.; Omer, S. B.; Ortblad, K.; Osborne, R.; Ozgediz, D.; Pahari, B.; Pandian, J. D.; Rivero, A. P.; Padilla, R. P.; PerezRuiz, F.; Perico, N.; Phillips, D.; Pierce, K.; Pope, C. A.; Porrini, E.; Pourmalek, F.; Raju, M.; Ranganathan, D.; Rehm, J. T.; Rein, D. B.; Remuzzi, G.; Rivara, F. P.; Roberts, T.; De León, F. R.; Rosenfeld, L. C.; Rushton, L.; Sacco, R. L.; Salomon, J. A.; Sampson, U.; Sanman, E.; Schwebel, D. C.; Segui-Gomez, M.; Shepard, D. S.; Singh, D.; Singleton, J.; Sliwa, K.; Smith, E.; Steer, A.; Taylor, J. A.; Thomas, B.; Tleyjeh, I. M.; Towbin, J. A.; Truelsen, T.; Undurraga, E. A.; Venketasubramanian, N.; Vijayakumar, L.; Vos, T.; Wagner, G. R.; Wang, M.; Wang, W.; Watt, K.; Weinstock, M. A.; Weintraub, R.; Wilkinson, J. D.; Woolf, A. D.; Wulf, S.; Yeh, P.-H.; Yip, P.; Zabetian, A.; Zheng, Z.-J.; Lopez, A. D.; Murray, C. J. L.; AlMazroa, M. A.; Memish, Z. A. Global and Regional Mortality from 235 Causes of Death for 20 Age Groups in 1990 and 2010: A Systematic Analysis for the Global Burden of Disease Study 2010. Lancet 2012, 380, 2095-2128.

(46) Stern, S.; Behar, S.; Gottlieb, S. Cardiology Patient Pages. Aging and Diseases of the Heart. Circulation 2003, 108, e99-101.

(47) North, B. J.; Sinclair, D. A. The Intersection between Aging and Cardiovascular Disease. Circ. Res. 2012, 110, 1097-1108.

(48) Bartke, A. Insulin and Aging. Cell Cycle 2008, 7, 3338-3343.

(49) Junnila, R. K.; List, E. O.; Berryman, D. E.; Murrey, J. W.; Kopchick, J. J. The GH/IGF1 Axis in Ageing and Longevity. Nat. Rev. Endocrinol. 2013, 9, 366-376.

(50) Corella, D.; Ordovás, J. M. Aging and Cardiovascular Diseases: The Role of Gene-Diet Interactions. Ageing Res. Rev. 2014, 18C, 53-73.

(51) Harrison, D. E.; Strong, R.; Sharp, Z. D.; Nelson, J. F.; Astle, C. M.; Flurkey, K.; Nadon, N. L.; Wilkinson, J. E.; Frenkel, K.; Carter, C. S.; Pahor, M.; Javors, M. A.; Fernandez, E.; Miller, R. A. Rapamycin Fed Late in Life Extends Lifespan in Genetically Heterogeneous Mice. Nature 2009, 460, 392-395.

(52) Hu, F.; Liu, F. Targeting Tissue-Specific Metabolic Signaling Pathways in Aging: The Promise and Limitations. Protein Cell 2013.

(53) Apfeld, J.; O'Connor, G.; McDonagh, T.; DiStefano, P. S.; Curtis, R. The AMPActivated Protein Kinase AAK-2 Links Energy Levels and Insulin-like Signals to Lifespan in C. Elegans. Genes Dev. 2004, 18, 3004-3009.

(54) Ruderman, N. B.; Carling, D.; Prentki, M.; Cacicedo, J. M. AMPK, Insulin Resistance, and the Metabolic Syndrome. J. Clin. Invest. 2013, 123, 2764-2772. 
(55) Zaha, V. G.; Young, L. H. AMP-Activated Protein Kinase Regulation and Biological Actions in the Heart. Circ. Res. 2012, 111, 800-814.

(56) Kang, C. B.; Hong, Y.; Dhe-Paganon, S.; Yoon, H. S. FKBP Family Proteins: Immunophilins with Versatile Biological Functions. Neurosignals. 2008, 16, 318-325.

(57) MacMillan, D. FK506 Binding Proteins: Cellular Regulators of Intracellular Ca2+ Signalling. Eur. J. Pharmacol. 2013, 700, 181-193.

(58) Shou, W.; Aghdasi, B.; Armstrong, D. L.; Guo, Q.; Bao, S.; Charng, M. J.; Mathews, L. M.; Schneider, M. D.; Hamilton, S. L.; Matzuk, M. M. Cardiac Defects and Altered Ryanodine Receptor Function in Mice Lacking FKBP12. Nature 1998, 391, 489-492.

(59) Maruyama, M.; Li, B.-Y.; Chen, H.; Xu, X.; Song, L.-S.; Guatimosim, S.; Zhu, W.; Yong, W.; Zhang, W.; Bu, G.; Lin, S.-F.; Fishbein, M. C.; Lederer, W. J.; Schild, J. H.; Field, L. J.; Rubart, M.; Chen, P.-S.; Shou, W. FKBP12 Is a Critical Regulator of the Heart Rhythm and the Cardiac Voltage-Gated Sodium Current in Mice. Circ. Res. 2011, $108,1042-1052$.

(60) Li, B.-Y.; Chen, H.; Maruyama, M.; Zhang, W.; Zhang, J.; Pan, Z.-W.; Rubart, M.; Chen, P.-S.; Shou, W. The Role of FK506-Binding Proteins 12 and 12.6 in Regulating Cardiac Function. Pediatr. Cardiol. 2012, 33, 988-994.

(61) Chiasson, V. L.; Talreja, D.; Young, K. J.; Chatterjee, P.; Banes-Berceli, A. K.; Mitchell, B. M. FK506 Binding Protein 12 Deficiency in Endothelial and Hematopoietic Cells Decreases Regulatory T Cells and Causes Hypertension. Hypertension 2011, 57, 11671175 .

(62) Lanner, J. T.; Georgiou, D. K.; Joshi, A. D.; Hamilton, S. L. Ryanodine Receptors: Structure, Expression, Molecular Details, and Function in Calcium Release. Cold Spring Harb. Perspect. Biol. 2010, 2, a003996.

(63) Driessen, H. E.; Bourgonje, V. J. A.; van Veen, T. A. B.; Vos, M. A. New Antiarrhythmic Targets to Control Intracellular Calcium Handling. Neth. Heart J. 2014, 22, 198-213.

(64) Dornan, J.; Taylor, P.; Walkinshaw, M. D. Structures of Immunophilins and Their Ligand Complexes. Curr. Top. Med. Chem. 2003, 3, 1392-1409.

(65) Wang, P.; Heitman, J. The Cyclophilins. Genome Biol. 2005, 6, 226.

(66) Sherry, B.; Yarlett, N.; Strupp, A.; Cerami, A. Identification of Cyclophilin as a Proinflammatory Secretory Product of Lipopolysaccharide-Activated Macrophages. Proc. Natl. Acad. Sci. U. S. A. 1992, 89, 3511-3515.

(67) Suzuki, J.; Jin, Z.-G.; Meoli, D. F.; Matoba, T.; Berk, B. C. Cyclophilin A Is Secreted by a Vesicular Pathway in Vascular Smooth Muscle Cells. Circ. Res. 2006, 98, 811817. 
(68) Griendling, K. K.; FitzGerald, G. A. Oxidative Stress and Cardiovascular Injury: Part II: Animal and Human Studies. Circulation 2003, 108, 2034-2040.

(69) Satoh, K.; Matoba, T.; Suzuki, J.; O’Dell, M. R.; Nigro, P.; Cui, Z.; Mohan, A.; Pan, S.; Li, L.; Jin, Z.-G.; Yan, C.; Abe, J.; Berk, B. C. Cyclophilin A Mediates Vascular Remodeling by Promoting Inflammation and Vascular Smooth Muscle Cell Proliferation. Circulation 2008, 117, 3088-3098.

(70) Nigro, P.; Pompilio, G.; Capogrossi, M. C. Cyclophilin A: A Key Player for Human Disease. Cell Death Dis. 2013, 4, e888.

(71) Satoh, K.; Nigro, P.; Zeidan, A.; Soe, N. N.; Jaffré, F.; Oikawa, M.; O’Dell, M. R.; Cui, Z.; Menon, P.; Lu, Y.; Mohan, A.; Yan, C.; Blaxall, B. C.; Berk, B. C. Cyclophilin A Promotes Cardiac Hypertrophy in Apolipoprotein E-Deficient Mice. Arterioscler. Thromb. Vasc. Biol. 2011, 31, 1116-1123.

(72) Yan, J.; Zang, X.; Chen, R.; Yuan, W.; Gong, J.; Wang, C.; Li, Y. The Clinical Implications of Increased Cyclophilin A Levels in Patients with Acute Coronary Syndromes. Clin. Chim. Acta. 2012, 413, 691-695.

(73) Alam, M. R.; Baetz, D.; Ovize, M. Cyclophilin D and Myocardial Ischemia-Reperfusion Injury: A Fresh Perspective. J. Mol. Cell. Cardiol. 2014.

(74) Johnson, N.; Khan, A.; Virji, S.; Ward, J. M.; Crompton, M. Import and Processing of Heart Mitochondrial Cyclophilin D. Eur. J. Biochem. 1999, 263, 353-359.

(75) Toko, H.; Konstandin, M. H.; Doroudgar, S.; Ormachea, L.; Joyo, E.; Joyo, A. Y.; Din, S.; Gude, N. A.; Collins, B.; Völkers, M.; Thuerauf, D. J.; Glembotski, C. C.; Chen, C.H.; Lu, K. P.; Müller, O. J.; Uchida, T.; Sussman, M. A. Regulation of Cardiac Hypertrophic Signaling by Prolyl Isomerase Pin1. Circ. Res. 2013, 112, 1244-1252.

(76) Resnick, H. E.; Harris, M. I.; Brock, D. B.; Harris, T. B. American Diabetes Association Diabetes Diagnostic Criteria, Advancing Age, and Cardiovascular Disease Risk Profiles: Results from the Third National Health and Nutrition Examination Survey. Diabetes Care 2000, 23, 176-180.

(77) Morley, J. E. Diabetes and Aging: Epidemiologic Overview. Clin. Geriatr. Med. 2008, 24, 395-405, v.

(78) Prentki, M.; Nolan, C. J. Islet Beta Cell Failure in Type 2 Diabetes. J. Clin. Invest. 2006, 116, 1802-1812.

(79) De Tata, V. Age-Related Impairment of Pancreatic Beta-Cell Function: Pathophysiological and Cellular Mechanisms. Front. Endocrinol. (Lausanne). 2014, 5, 138.

(80) Desgraz, R.; Bonal, C.; Herrera, P. L. B-Cell Regeneration: The Pancreatic Intrinsic Faculty. Trends Endocrinol. Metab. 2011, 22, 34-43. 
(81) Sharpless, N. E.; DePinho, R. a. How Stem Cells Age and Why This Makes Us Grow Old. Nat. Rev. Mol. Cell Biol. 2007, 8, 703-713.

(82) Kushner, J. A. The Role of Aging upon B Cell Turnover. J. Clin. Invest. 2013, 123, 990995.

(83) Krishnamurthy, J.; Ramsey, M. R.; Ligon, K. L.; Torrice, C.; Koh, A.; Bonner-Weir, S.; Sharpless, N. E. p16INK4a Induces an Age-Dependent Decline in Islet Regenerative Potential. Nature 2006, 443, 453-457.

(84) Newgard, C. B.; Sharpless, N. E. Coming of Age: Molecular Drivers of Aging and Therapeutic Opportunities. J. Clin. Invest. 2013, 123, 946-950.

(85) Pereira, M. J.; Palming, J.; Svensson, M. K.; Rizell, M.; Dalenbäck, J.; Hammar, M.; Fall, T.; Sidibeh, C. O.; Svensson, P.-A.; Eriksson, J. W. FKBP5 Expression in Human Adipose Tissue Increases Following Dexamethasone Exposure and Is Associated with Insulin Resistance. Metabolism. 2014, 63, 1198-1208.

(86) Balsevich, G.; Uribe, A.; Wagner, K. V; Hartmann, J.; Santarelli, S.; Labermaier, C.; Schmidt, M. V. Interplay between Diet-Induced Obesity and Chronic Stress in Mice: Potential Role of FKBP51. J. Endocrinol. 2014, 222, 15-26.

(87) Ramachandran, S.; Kartha, C. C. Cyclophilin-A: A Potential Screening Marker for Vascular Disease in Type-2 Diabetes. Can. J. Physiol. Pharmacol. 2012, 90, 10051015.

(88) Roderick, P.; Roth, M.; Mindell, J. Prevalence of Chronic Kidney Disease in England: Findings from the 2009 Health Survey for England. J. Epidemiol. Community Heal. 2011, 65, A12-A12.

(89) Jha, V.; Garcia-Garcia, G.; Iseki, K.; Li, Z.; Naicker, S.; Plattner, B.; Saran, R.; Wang, A. Y.-M.; Yang, C.-W. Chronic Kidney Disease: Global Dimension and Perspectives. Lancet 2013, 382, 260-272.

(90) Levey, A. S.; Coresh, J. Chronic Kidney Disease. Lancet 2012, 379, 165-180.

(91) Nasrallah, R.; Hassouneh, R.; Hébert, R. L. Chronic Kidney Disease: Targeting Prostaglandin E2 Receptors. Am. J. Physiol. Renal Physiol. 2014, 307, F243-50.

(92) Tonelli, M.; Riella, M. C. Chronic Kidney Disease and the Aging Population. Kidney Int. 2014, 85, 487-491.

(93) Lu, M.-K.; Gong, X.-G.; Guan, K.-L. mTOR in Podocyte Function: Is Rapamycin Good for Diabetic Nephropathy? Cell Cycle 2011, 10, 3415-3416.

(94) Merscher, S.; Fornoni, A. Podocyte Pathology and Nephropathy - Sphingolipids in Glomerular Diseases. Front. Endocrinol. (Lausanne). 2014, 5, 127.

(95) Henique, C.; Tharaux, P.-L. Targeting Signaling Pathways in Glomerular Diseases. Curr. Opin. Nephrol. Hypertens. 2012, 21, 417-427. 
(96) Loffing, J.; Korbmacher, C. Regulated Sodium Transport in the Renal Connecting Tubule (CNT) via the Epithelial Sodium Channel (ENaC). Pflugers Arch. 2009, 458, $111-135$.

(97) Whaley-Connell, A.; Sowers, J. R. Oxidative Stress in the Cardiorenal Metabolic Syndrome. Curr. Hypertens. Rep. 2012, 14, 360-365.

(98) Ueda, K.; Fujiki, K.; Shirahige, K.; Gomez-Sanchez, C. E.; Fujita, T.; Nangaku, M.; Nagase, M. Genome-Wide Analysis of Murine Renal Distal Convoluted Tubular Cells for the Target Genes of Mineralocorticoid Receptor. Biochem. Biophys. Res. Commun. 2014, 445, 132-137.

(99) Nagase, M. [Mineralocorticoid Receptor: An Update]. Nihon Rinsho. 2012, 70, 15041509 .

(100) Nagase, R.; Kajitani, N.; Shikata, K.; Ogawa, D.; Kodera, R.; Okada, S.; Kido, Y.; Makino, H. Phenotypic Change of Macrophages in the Progression of Diabetic Nephropathy; Sialoadhesin-Positive Activated Macrophages Are Increased in Diabetic Kidney. Clin. Exp. Nephrol. 2012, 16, 739-748.

(101) Han, I. S.; Nakagawa, Y.; Park, J. W.; Suh, M. H.; Suh, S. Il; Shin, S. W.; Ahn, S. Y.; Choe, B. K. FKBP-12 Exhibits an Inhibitory Activity on Calcium Oxalate Crystal Growth in Vitro. J. Korean Med. Sci. 2002, 17, 41.

(102) Glew, R. H.; Sun, Y.; Horowitz, B. L.; Konstantinov, K. N.; Barry, M.; Fair, J. R.; Massie, L.; Tzamaloukas, A. H. Nephropathy in Dietary Hyperoxaluria: A Potentially Preventable Acute or Chronic Kidney Disease. World J. Nephrol. 2014, 3, 122-142.

(103) Ivanovski, O.; Drüeke, T. B. A New Era in the Treatment of Calcium Oxalate Stones? Kidney Int. 2013, 83, 998-1000.

(104) Keddis, M. T.; Rule, A. D. Nephrolithiasis and Loss of Kidney Function. Curr. Opin. Nephrol. Hypertens. 2013, 22, 390-396.

(105) Li, H.; Klett, D. E.; Littleton, R.; Elder, J. S.; Sammon, J. D. Role of Insulin Resistance in Uric Acid Nephrolithiasis. World J. Nephrol. 2014, 3, 237-242.

(106) Sakhaee, K.; Maalouf, N. M.; Sinnott, B. Clinical Review. Kidney Stones 2012: Pathogenesis, Diagnosis, and Management. J. Clin. Endocrinol. Metab. 2012, 97, 18471860.

(107) Smyth, L. J.; McKay, G. J.; Maxwell, A. P.; McKnight, A. J. DNA Hypermethylation and DNA Hypomethylation Is Present at Different Loci in Chronic Kidney Disease. Epigenetics 2014, 9, 366-376.

(108) Petrovich, E.; Asher, C.; Garty, H. Induction of FKBP51 by Aldosterone in Intestinal Epithelium. J. Steroid Biochem. Mol. Biol. 2014, 139, 78-87.

(109) Gumz, M.; Richards, J.; Solocinski, K. Identification of Novel Aldosterone Targets in Mouse Kidney Cortical Collecting Duct Cells (744.1). FASEB J 2014, 28, 744.1-. 
(110) Ponda, M. P.; Hostetter, T. H. Aldosterone Antagonism in Chronic Kidney Disease. Clin. J. Am. Soc. Nephrol. 2006, 1, 668-677.

(111) Watanabe, S.; Tsuruoka, S.; Vijayakumar, S.; Fischer, G.; Zhang, Y.; Fujimura, A.; AlAwqati, Q.; Schwartz, G. J. Cyclosporin A Produces Distal Renal Tubular Acidosis by Blocking Peptidyl Prolyl Cis-Trans Isomerase Activity of Cyclophilin. Am. J. Physiol. Renal Physiol. 2005, 288, F40-7.

(112) Komers, R.; Mar, D.; Denisenko, O.; Xu, B.; Oyama, T. T.; Bomsztyk, K. Epigenetic Changes in Renal Genes Dysregulated in Mouse and Rat Models of Type 1 Diabetes. Lab. Invest. 2013, 93, 543-552.

(113) Yang, J.; Li, A.; Yang, Y.; Li, X. Identification of Cyclophilin A as a Potential Prognostic Factor for Clear-Cell Renal Cell Carcinoma by Comparative Proteomic Analysis. Cancer Biol. Ther. 2011, 11, 535-546.

(114) Kumar, R. Pin1 Regulates Parathyroid Hormone mRNA Stability. J. Clin. Invest. 2009, 119, 2887-2891.

(115) Bredesen, D. E.; Rao, R. V; Mehlen, P. Cell Death in the Nervous System. Nature 2006, 443, 796-802.

(116) Thompson, L. M. Neurodegeneration: A Question of Balance. Nature 2008, 452, 707708.

(117) Rubinsztein, D. C. The Roles of Intracellular Protein-Degradation Pathways in Neurodegeneration. 2006, 443, 780-786.

(118) Lansbury, P. T.; Lashuel, H. A. A Century-Old Debate on Protein Aggregation and Neurodegeneration Enters the Clinic. Nature 2006, 443, 774-779.

(119) O' Neill, C. PI3-kinase/Akt/mTOR Signaling: Impaired On/off Switches in Aging, Cognitive Decline and Alzheimer's Disease. Exp. Gerontol. 2013, 48, 647-653.

(120) Heras-Sandoval, D.; Pérez-Rojas, J. M.; Hernández-Damián, J.; Pedraza-Chaverri, J. The Role of PI3K/AKT/mTOR Pathway in the Modulation of Autophagy and the Clearance of Protein Aggregates in Neurodegeneration. Cell. Signal. 2014, 26, 2694 2701.

(121) Michaelson, D. M. ApoE4: The Most Prevalent yet Understudied Risk Factor for Alzheimer's Disease. Alzheimers. Dement. 2014.

(122) Kadish, I.; Thibault, O.; Blalock, E. M.; Chen, K.-C.; Gant, J. C.; Porter, N. M.; Landfield, P. W. Hippocampal and Cognitive Aging across the Lifespan: A Bioenergetic Shift Precedes and Increased Cholesterol Trafficking Parallels Memory Impairment. $J$. Neurosci. 2009, 29, 1805-1816.

(123) Hindle, J. V. Ageing, Neurodegeneration and Parkinson's Disease. Age Ageing 2010, $39,156-161$. 
(124) Beitz, J. M. Parkinson's Disease: A Review. Front. Biosci. (Schol. Ed). 2014, 6, 65-74.

(125) Lees, A. J.; Hardy, J.; Revesz, T. Parkinson's Disease. Lancet 2009, 373, 2055-2066.

(126) Reeve, A.; Simcox, E.; Turnbull, D. Ageing and Parkinson's Disease: Why Is Advancing Age the Biggest Risk Factor? Ageing Res. Rev. 2014, 14, 19-30.

(127) Kalia, L. V; Kalia, S. K.; McLean, P. J.; Lozano, A. M.; Lang, A. E. A-Synuclein Oligomers and Clinical Implications for Parkinson Disease. Ann. Neurol. 2013, 73, 155169.

(128) Malagelada, C.; Jin, Z. H.; Greene, L. A. RTP801 Is Induced in Parkinson's Disease and Mediates Neuron Death by Inhibiting Akt Phosphorylation/activation. J. Neurosci. 2008, 28, 14363-14371.

(129) Malagelada, C.; Jin, Z. H.; Jackson-Lewis, V.; Przedborski, S.; Greene, L. A. Rapamycin Protects against Neuron Death in in Vitro and in Vivo Models of Parkinson's Disease. J. Neurosci. 2010, 30, 1166-1175.

(130) Gant, J. C.; Chen, K.-C.; Norris, C. M.; Kadish, I.; Thibault, O.; Blalock, E. M.; Porter, N. M.; Landfield, P. W. Disrupting Function of FK506-Binding Protein 1b/12.6 Induces the $\mathrm{Ca}^{2}+$-Dysregulation Aging Phenotype in Hippocampal Neurons. J. Neurosci. 2011, $31,1693-1703$.

(131) Cao, W.; Konsolaki, M. FKBP Immunophilins and Alzheimer's Disease: A Chaperoned Affair. J. Biosci. 2011, 36, 493-498.

(132) Liu, F.-L.; Liu, P.-H.; Shao, H.-W.; Kung, F.-L. The Intracellular Domain of Amyloid Precursor Protein Interacts with FKBP12. Biochem. Biophys. Res. Commun. 2006, 350, $472-477$.

(133) Gant, J. C.; Blalock, E. M.; Chen, K.-C.; Kadish, I.; Porter, N. M.; Norris, C. M.; Thibault, O.; Landfield, P. W. FK506-Binding Protein 1b/12.6: A Key to Aging-Related Hippocampal Ca2+ Dysregulation? Eur. J. Pharmacol. 2014, 739, 74-82.

(134) Liu, F.-L.; Liu, T.-Y.; Kung, F.-L. FKBP12 Regulates the Localization and Processing of Amyloid Precursor Protein in Human Cell Lines. J. Biosci. 2014, 39, 85-95.

(135) Shirane, M.; Nakayama, K. I. Inherent Calcineurin Inhibitor FKBP38 Targets Bcl-2 to Mitochondria and Inhibits Apoptosis. Nat. Cell Biol. 2003, 5, 28-37.

(136) Wang, H.-Q.; Nakaya, Y.; Du, Z.; Yamane, T.; Shirane, M.; Kudo, T.; Takeda, M.; Takebayashi, K.; Noda, Y.; Nakayama, K. I.; Nishimura, M. Interaction of Presenilins with FKBP38 Promotes Apoptosis by Reducing Mitochondrial Bcl-2. Hum. Mol. Genet. 2005, 14, 1889-1902.

(137) Shimamoto, S.; Tsuchiya, M.; Yamaguchi, F.; Kubota, Y.; Tokumitsu, H.; Kobayashi, R. Ca2+/S100 Proteins Inhibit the Interaction of FKBP38 with Bcl-2 and Hsp90. Biochem. J. 2014, 458, 141-152. 
(138) Edlich, F.; Lücke, C. From Cell Death to Viral Replication: The Diverse Functions of the Membrane-Associated FKBP38. Curr. Opin. Pharmacol. 2011, 11, 348-353.

(139) Jinwal, U. K.; Koren, J.; Borysov, S. I.; Schmid, A. B.; Abisambra, J. F.; Blair, L. J.; Johnson, A. G.; Jones, J. R.; Shults, C. L.; O’Leary, J. C.; Jin, Y.; Buchner, J.; Cox, M. B.; Dickey, C. A. The Hsp90 Cochaperone, FKBP51, Increases Tau Stability and Polymerizes Microtubules. J. Neurosci. 2010, 30, 591-599.

(140) Yakkundi, A.; Robson, T.; McKeen, H. . Steroid Receptor Signalling in Cancer: A Focus on FK506 - Binding Proteins. Recent Res. Dev. Endocrinol. 2014, 5, 21-39.

(141) Storer, C. L.; Dickey, C. a; Galigniana, M. D.; Rein, T.; Cox, M. B. FKBP51 and FKBP52 in Signaling and Disease. Trends Endocrinol. Metab. 2011, 22, 481-490.

(142) Chambraud, B.; Belabes, H.; Fontaine-Lenoir, V.; Fellous, A.; Baulieu, E. E. The Immunophilin FKBP52 Specifically Binds to Tubulin and Prevents Microtubule Formation. FASEB J. 2007, 21, 2787-2797.

(143) Salminen, A.; Ojala, J.; Kaarniranta, K.; Hiltunen, M.; Soininen, H. Hsp90 Regulates Tau Pathology through Co-Chaperone Complexes in Alzheimer's Disease. Prog. Neurobiol. 2011, 93, 99-110.

(144) Sanokawa-Akakura, R.; Cao, W.; Allan, K.; Patel, K.; Ganesh, A.; Heiman, G.; Burke, R.; Kemp, F. W.; Bogden, J. D.; Camakaris, J.; Birge, R. B.; Konsolaki, M. Control of Alzheimer's Amyloid Beta Toxicity by the High Molecular Weight Immunophilin FKBP52 and Copper Homeostasis in Drosophila. PLoS One 2010, 5, e8626.

(145) Bellingham, S. A.; Lahiri, D. K.; Maloney, B.; La Fontaine, S.; Multhaup, G.; Camakaris, J. Copper Depletion down-Regulates Expression of the Alzheimer's Disease Amyloid-Beta Precursor Protein Gene. J. Biol. Chem. 2004, 279, 20378-20386.

(146) Sanokawa-Akakura, R.; Dai, H.; Akakura, S.; Weinstein, D.; Fajardo, J. E.; Lang, S. E.; Wadsworth, S.; Siekierka, J.; Birge, R. B. A Novel Role for the Immunophilin FKBP52 in Copper Transport. J. Biol. Chem. 2004, 279, 27845-27848.

(147) Conejero-Goldberg, C.; Hyde, T. M.; Chen, S.; Dreses-Werringloer, U.; Herman, M. M.; Kleinman, J. E.; Davies, P.; Goldberg, T. E. Molecular Signatures in Post-Mortem Brain Tissue of Younger Individuals at High Risk for Alzheimer's Disease as Based on APOE Genotype. Mol. Psychiatry 2011, 16, 836-847.

(148) Bell, R. D.; Winkler, E. A.; Singh, I.; Sagare, A. P.; Deane, R.; Wu, Z.; Holtzman, D. M.; Betsholtz, C.; Armulik, A.; Sallstrom, J.; Berk, B. C.; Zlokovic, B. V. Apolipoprotein E Controls Cerebrovascular Integrity via Cyclophilin A. Nature 2012, $485,512-516$.

(149) Pagani, L.; Eckert, A. Amyloid-Beta Interaction with Mitochondria. Int. J. Alzheimers. Dis. 2011, 2011, 925050. 
(150) Buée, L.; Bussière, T.; Buée-Scherrer, V.; Delacourte, A.; Hof, P. R. Tau Protein Isoforms, Phosphorylation and Role in Neurodegenerative Disorders. Brain Res. Brain Res. Rev. 2000, 33, 95-130.

(151) Smith, W.; Assink, J.; Klein, R.; Mitchell, P.; Klaver, C. C.; Klein, B. E.; Hofman, A.; Jensen, S.; Wang, J. J.; de Jong, P. T. Risk Factors for Age-Related Macular Degeneration: Pooled Findings from Three Continents. Ophthalmology 2001, 108, 697704.

(152) Lim, L. S.; Mitchell, P.; Seddon, J. M.; Holz, F. G.; Wong, T. Y. Age-Related Macular Degeneration. Lancet 2012, 379, 1728-1738.

(153) Tuo, J.; Bojanowski, C. M.; Chan, C.-C. Genetic Factors of Age-Related Macular Degeneration. Prog. Retin. Eye Res. 2004, 23, 229-249.

(154) Cipriani, V.; Leung, H.-T.; Plagnol, V.; Bunce, C.; Khan, J. C.; Shahid, H.; Moore, A. T.; Harding, S. P.; Bishop, P. N.; Hayward, C.; Campbell, S.; Armbrecht, A. M.; Dhillon, B.; Deary, I. J.; Campbell, H.; Dunlop, M.; Dominiczak, A. F.; Mann, S. S.; Jenkins, S. A.; Webster, A. R.; Bird, A. C.; Lathrop, M.; Zelenika, D.; Souied, E. H.; Sahel, J.-A.; Léveillard, T.; Cree, A. J.; Gibson, J.; Ennis, S.; Lotery, A. J.; Wright, A. F.; Clayton, D. G.; Yates, J. R. W. Genome-Wide Association Study of Age-Related Macular Degeneration Identifies Associated Variants in the TNXB-FKBPL-NOTCH4 Region of Chromosome 6p21.3. Hum. Mol. Genet. 2012, 21, 4138-4150.

(155) Cipriani, V.; Leung, H.; Plagnol, V.; Bunce, C.; Jane, C.; Shahid, H.; Moore, A. T.; Harding, S. P.; Paul, N.; Hayward, C.; Campbell, S.; Armbrecht, A. M.; Deary, I. J.; Campbell, H.; Dunlop, M.; Anna, F.; Mann, S. S.; Jenkins, S. A.; Webster, A. R.; Bird, A. C.; Zelenika, D.; Souied, E. H. HMG Advance Access Published June 13, 20121. 2012, 1-34.

(156) Blagosklonny, M. V. Molecular Theory of Cancer. Cancer Biol. Ther. 2005, 4, 621627.

(157) Reya, T.; Morrison, S. J.; Clarke, M. F.; Weissman, I. L. Stem Cells, Cancer, and Cancer Stem Cells. Nature 2001, 414, 105-111.

(158) Hanahan, D.; Weinberg, R. A. Hallmarks of Cancer: The next Generation. Cell 2011, 144, 646-674.

(159) Sudarsanam, S.; Johnson, D. E. Functional Consequences of mTOR Inhibition. Curr. Opin. Drug Discov. Devel. 2010, 13, 31-40.

(160) O’Reilly, K. E.; Rojo, F.; She, Q.-B.; Solit, D.; Mills, G. B.; Smith, D.; Lane, H.; Hofmann, F.; Hicklin, D. J.; Ludwig, D. L.; Baselga, J.; Rosen, N. mTOR Inhibition Induces Upstream Receptor Tyrosine Kinase Signaling and Activates Akt. Cancer Res. 2006, 66, 1500-1508.

(161) Higgins, J. P. T.; Montgomery, K.; Wang, L.; Domanay, E.; Warnke, R. A.; Brooks, J. D.; van de Rijn, M. Expression of FKBP12 in Benign and Malignant Vascular 
Endothelium: An Immunohistochemical Study on Conventional Sections and Tissue Microarrays. Am. J. Surg. Pathol. 2003, 27, 58-64.

(162) Aghdasi, B.; Ye, K.; Resnick, A.; Huang, A.; Ha, H. C.; Guo, X.; Dawson, T. M.; Dawson, V. L.; Snyder, S. H. FKBP12, the 12-kDa FK506-Binding Protein, Is a Physiologic Regulator of the Cell Cycle. Proc. Natl. Acad. Sci. U. S. A. 2001, 98, 24252430.

(163) Romano, S.; Mallardo, M.; Chiurazzi, F.; Bisogni, R.; D’Angelillo, A.; Liuzzi, R.; Compare, G.; Romano, M. F. The Effect of FK506 on Transforming Growth Factor Beta Signaling and Apoptosis in Chronic Lymphocytic Leukemia B Cells. Haematologica 2008, 93, 1039-1048.

(164) Ahearn, I. M.; Tsai, F. D.; Court, H.; Zhou, M.; Jennings, B. C.; Ahmed, M.; Fehrenbacher, N.; Linder, M. E.; Philips, M. R. FKBP12 Binds to Acylated H-Ras and Promotes Depalmitoylation. Mol. Cell 2011, 41, 173-185.

(165) Siamakpour-Reihani, S.; Caster, J.; Bandhu Nepal, D.; Courtwright, A.; Hilliard, E.; Usary, J.; Ketelsen, D.; Darr, D.; Shen, X. J.; Patterson, C.; Klauber-Demore, N. The Role of calcineurin/NFAT in SFRP2 Induced Angiogenesis--a Rationale for Breast Cancer Treatment with the Calcineurin Inhibitor Tacrolimus. PLoS One 2011, 6, e20412.

(166) Tomek, M.; Akiyama, T.; Dass, C. R. Role of Bcl-2 in Tumour Cell Survival and Implications for Pharmacotherapy. J. Pharm. Pharmacol. 2012, 64, 1695-1702.

(167) Wu, S.; Wang, X.; Chen, J.; Chen, Y. Autophagy of Cancer Stem Cells Is Involved with Chemoresistance of Colon Cancer Cells. Biochem. Biophys. Res. Commun. 2013, 434, 898-903.

(168) Cox, M. B.; Smith, D. F. Functions of the Hsp90-Binding FKBP Immunophilins, 2000.

(169) Jääskeläinen, T.; Makkonen, H.; Palvimo, J. J. Steroid up-Regulation of FKBP51 and Its Role in Hormone Signaling. Curr. Opin. Pharmacol. 2011, 11, 326-331.

(170) Pei, H.; Li, L.; Fridley, B. L.; Jenkins, G. D.; Kalari, K. R.; Lingle, W.; Petersen, G.; Lou, Z.; Wang, L. FKBP51 Affects Cancer Cell Response to Chemotherapy by Negatively Regulating Akt. Cancer Cell 2009, 16, 259-266.

(171) Bouwmeester, T.; Bauch, A.; Ruffner, H.; Angrand, P.-O.; Bergamini, G.; Croughton, K.; Cruciat, C.; Eberhard, D.; Gagneur, J.; Ghidelli, S.; Hopf, C.; Huhse, B.; Mangano, R.; Michon, A.-M.; Schirle, M.; Schlegl, J.; Schwab, M.; Stein, M. A.; Bauer, A.; Casari, G.; Drewes, G.; Gavin, A.-C.; Jackson, D. B.; Joberty, G.; Neubauer, G.; Rick, J.; Kuster, B.; Superti-Furga, G. A Physical and Functional Map of the Human TNFalpha/NF-Kappa B Signal Transduction Pathway. Nat. Cell Biol. 2004, 6, 97-105.

(172) Romano, S.; Mallardo, M.; Romano, M. F. FKBP51 and the NF- $\kappa$ B Regulatory Pathway in Cancer. Curr. Opin. Pharmacol. 2011, 11, 288-293. 
(173) Romano, S.; Staibano, S.; Greco, A.; Brunetti, A.; Nappo, G.; Ilardi, G.; Martinelli, R.; Sorrentino, A.; Di Pace, A.; Mascolo, M.; Bisogni, R.; Scalvenzi, M.; Alfano, B.; Romano, M. F. FK506 Binding Protein 51 Positively Regulates Melanoma Stemness and Metastatic Potential. Cell Death Dis. 2013, 4, e578.

(174) Stechschulte, L. A.; Sanchez, E. R. FKBP51-a Selective Modulator of Glucocorticoid and Androgen Sensitivity. Curr. Opin. Pharmacol. 2011, 11, 332-337.

(175) Amler, L. C.; Agus, D. B.; LeDuc, C.; Sapinoso, M. L.; Fox, W. D.; Kern, S.; Lee, D.; Wang, V.; Leysens, M.; Higgins, B.; Martin, J.; Gerald, W.; Dracopoli, N.; CordonCardo, C.; Scher, H. I.; Hampton, G. M. Dysregulated Expression of AndrogenResponsive and Nonresponsive Genes in the Androgen-Independent Prostate Cancer Xenograft Model CWR22-R1. Cancer Res. 2000, 60, 6134-6141.

(176) Suzuki, Y.; Kondo, Y.; Hara, S.; Kimata, R.; Nishimura, T. Effect of the hsp90 Inhibitor Geldanamycin on Androgen Response of Prostate Cancer under Hypoxic Conditions. Int. J. Urol. 2010, 17, 281-285.

(177) Lamoureux, F.; Thomas, C.; Yin, M.-J.; Kuruma, H.; Fazli, L.; Gleave, M. E.; Zoubeidi, A. A Novel HSP90 Inhibitor Delays Castrate-Resistant Prostate Cancer without Altering Serum PSA Levels and Inhibits Osteoclastogenesis. Clin. Cancer Res. 2011, 17, 23012313.

(178) Mukaide, H.; Adachi, Y.; Taketani, S.; Iwasaki, M.; Koike-Kiriyama, N.; Shigematsu, A.; Shi, M.; Yanai, S.; Yoshioka, K.; Kamiyama, Y.; Ikehara, S. FKBP51 Expressed by Both Normal Epithelial Cells and Adenocarcinoma of Colon Suppresses Proliferation of Colorectal Adenocarcinoma. Cancer Invest. 2008, 26, 385-390.

(179) De Leon, J. T.; Iwai, A.; Feau, C.; Garcia, Y.; Balsiger, H. A.; Storer, C. L.; Suro, R. M.; Garza, K. M.; Lee, S.; Kim, Y. S.; Chen, Y.; Ning, Y.-M.; Riggs, D. L.; Fletterick, R. J.; Guy, R. K.; Trepel, J. B.; Neckers, L. M.; Cox, M. B. Targeting the Regulation of Androgen Receptor Signaling by the Heat Shock Protein 90 Cochaperone FKBP52 in Prostate Cancer Cells. Proc. Natl. Acad. Sci. U. S. A. 2011, 108, 11878-11883.

(180) Ward, B. K.; Mark, P. J.; Ingram, D. M.; Minchin, R. F.; Ratajczak, T. Expression of the Estrogen Receptor-Associated Immunophilins, Cyclophilin 40 and FKBP52, in Breast Cancer. Breast Cancer Res. Treat. 1999, 58, 267-280.

(181) Desmetz, C.; Bascoul-Mollevi, C.; Rochaix, P.; Lamy, P.-J.; Kramar, A.; Rouanet, P.; Maudelonde, T.; Mangé, A.; Solassol, J. Identification of a New Panel of Serum Autoantibodies Associated with the Presence of in Situ Carcinoma of the Breast in Younger Women. Clin. Cancer Res. 2009, 15, 4733-4741.

(182) Sivils, J. C.; Storer, C. L.; Galigniana, M. D.; Cox, M. B. Regulation of Steroid Hormone Receptor Function by the 52-kDa FK506-Binding Protein (FKBP52). Curr. Opin. Pharmacol. 2011, 11, 314-319.

(183) Solassol, J.; Mange, A.; Maudelonde, T. FKBP Family Proteins as Promising New Biomarkers for Cancer. Curr. Opin. Pharmacol. 2011, 11, 320-325. 
(184) Olesen, S. H.; Christensen, L. L.; Sørensen, F. B.; Cabezón, T.; Laurberg, S.; Orntoft, T. F.; Birkenkamp-Demtröder, K. Human FK506 Binding Protein 65 Is Associated with Colorectal Cancer. Mol. Cell. Proteomics 2005, 4, 534-544.

(185) Quinn, M. C. J.; Wojnarowicz, P. M.; Pickett, A.; Provencher, D. M.; Mes-Masson, A.M.; Davis, E. C.; Tonin, P. N. FKBP10/FKBP65 Expression in High-Grade Ovarian Serous Carcinoma and Its Association with Patient Outcome. Int. J. Oncol. 2013, 42, 912-920.

(186) Henriksen, R.; Sørensen, F. B.; Ørntoft, T. F.; Birkenkamp-Demtroder, K. Expression of FK506 Binding Protein 65 (FKBP65) Is Decreased in Epithelial Ovarian Cancer Cells Compared to Benign Tumor Cells and to Ovarian Epithelium. Tumour Biol. 2011, 32, 671-676.

(187) McKeen, H. D.; Byrne, C.; Jithesh, P. V; Donley, C.; Valentine, A.; Yakkundi, A.; O’Rourke, M.; Swanton, C.; McCarthy, H. O.; Hirst, D. G.; Robson, T. FKBPL Regulates Estrogen Receptor Signaling and Determines Response to Endocrine Therapy. Cancer Res. 2010, 70, 1090-1100.

(188) Sunnotel, O.; Hiripi, L.; Lagan, K.; McDaid, J. R.; De León, J. M.; Miyagawa, Y.; Crowe, H.; Kaluskar, S.; Ward, M.; Scullion, C.; Campbell, A.; Downes, C. S.; Hirst, D.; Barton, D.; Mocanu, E.; Tsujimura, A.; Cox, M. B.; Robson, T.; Walsh, C. P. Alterations in the Steroid Hormone Receptor Co-Chaperone FKBPL Are Associated with Male Infertility: A Case-Control Study. Reprod. Biol. Endocrinol. 2010, 8, 22.

(189) McKeen, H. D.; McAlpine, K.; Valentine, A.; Quinn, D. J.; McClelland, K.; Byrne, C.; O’Rourke, M.; Young, S.; Scott, C. J.; McCarthy, H. O.; Hirst, D. G.; Robson, T. A Novel FK506-like Binding Protein Interacts with the Glucocorticoid Receptor and Regulates Steroid Receptor Signaling. Endocrinology 2008, 149, 5724-5734.

(190) Li, Y.-Y.; Liu, L.-Q.; Yang, J.; Liu, W.; Chen, X.-J.; Li, X.-Q.; Du, W.; Huang, S.-A. [Effect of WISp39 on Proliferation, Cell Cycle and Apoptosis of U937 Cells]. Zhongguo Shi Yan Xue Ye Xue Za Zhi 2007, 15, 733-737.

(191) Bublik, D. R.; Scolz, M.; Triolo, G.; Monte, M.; Schneider, C. Human GTSE-1 Regulates p21(CIP1/WAF1) Stability Conferring Resistance to Paclitaxel Treatment. $J$. Biol. Chem. 2010, 285, 5274-5281.

(192) Robson, T.; Price, M. E.; Moore, M. L.; Joiner, M. C.; McKelvey-Martin, V. J.; McKeown, S. R.; Hirst, D. G. Increased Repair and Cell Survival in Cells Treated with DIR1 Antisense Oligonucleotides: Implications for Induced Radioresistance. Int. J. Radiat. Biol. 2000, 76, 617-623.

(193) Valentine, A.; O’Rourke, M.; Yakkundi, A.; Worthington, J.; Hookham, M.; Bicknell, R.; McCarthy, H. O.; McClelland, K.; McCallum, L.; Dyer, H.; McKeen, H.; Waugh, D. J. J.; Roberts, J.; McGregor, J.; Cotton, G.; James, I.; Harrison, T.; Hirst, D. G.; Robson, T. FKBPL and Peptide Derivatives: Novel Biological Agents That Inhibit Angiogenesis by a CD44-Dependent Mechanism. Clin. Cancer Res. 2011, 17, 1044 1056. 
(194) McClements, L.; Yakkundi, A.; Papaspyropoulos, A.; Harrison, H.; Ablett, M. P.; Jithesh, P. V; McKeen, H. D.; Bennett, R.; Donley, C.; Kissenpfennig, A.; McIntosh, S.; McCarthy, H. O.; O’Neill, E.; Clarke, R. B.; Robson, T. Targeting Treatment-Resistant Breast Cancer Stem Cells with FKBPL and Its Peptide Derivative, AD-01, via the CD44 Pathway. Clin. Cancer Res. 2013, 19, 3881-3893.

(195) Yakkundi, A.; McCallum, L.; O’Kane, A.; Dyer, H.; Worthington, J.; McKeen, H. D.; McClements, L.; Elliott, C.; McCarthy, H. O.; Hirst, D. G.; Robson, T. The AntiMigratory Effects of FKBPL and Its Peptide Derivative, AD-01: Regulation of CD44 and the Cytoskeletal Pathway. PLoS One 2013, 8, e55075.

(196) Robson, T.; James, I. F. The Therapeutic and Diagnostic Potential of FKBPL; a Novel Anticancer Protein. Drug Discov. Today 2012, 17, 544-548.

(197) Howard, B. A.; Furumai, R.; Campa, M. J.; Rabbani, Z. N.; Vujaskovic, Z.; Wang, X.F.; Patz, E. F. Stable RNA Interference-Mediated Suppression of Cyclophilin A Diminishes Non-Small-Cell Lung Tumor Growth in Vivo. Cancer Res. 2005, 65, 88538860 .

(198) Yang, H.; Chen, J.; Yang, J.; Qiao, S.; Zhao, S.; Yu, L. Cyclophilin A Is Upregulated in Small Cell Lung Cancer and Activates ERK1/2 Signal. Biochem. Biophys. Res. Commun. 2007, 361, 763-767.

(199) Qi, Y.-J.; He, Q.-Y.; Ma, Y.-F.; Du, Y.-W.; Liu, G.-C.; Li, Y.-J.; Tsao, G. S. W.; Ngai, S. M.; Chiu, J.-F. Proteomic Identification of Malignant Transformation-Related Proteins in Esophageal Squamous Cell Carcinoma. J. Cell. Biochem. 2008, 104, 16251635.

(200) Obchoei, S.; Wongkhan, S.; Wongkham, C.; Li, M.; Yao, Q.; Chen, C. Cyclophilin A: Potential Functions and Therapeutic Target for Human Cancer. Med. Sci. Monit. 2009, 15, RA221-32.

(201) Lee, J.; Kim, S. An Overview of Cyclophilins in Human Cancers. J. Int. Med. Res. 2010, $38,1561-1574$.

(202) Li, Z.; Min, W.; Gou, J. Knockdown of Cyclophilin A Reverses Paclitaxel Resistance in Human Endometrial Cancer Cells via Suppression of MAPK Kinase Pathways. Cancer Chemother. Pharmacol. 2013, 72, 1001-1011.

(203) Choi, K. J.; Piao, Y. J.; Lim, M. J.; Kim, J. H.; Ha, J.; Choe, W.; Kim, S. S. Overexpressed Cyclophilin A in Cancer Cells Renders Resistance to Hypoxia- and Cisplatin-Induced Cell Death. Cancer Res. 2007, 67, 3654-3662.

(204) Bannon, J. H.; O’Donovan, D. S.; Kennelly, S. M. E.; Mc Gee, M. M. The Peptidyl Prolyl Isomerase Cyclophilin A Localizes at the Centrosome and the Midbody and Is Required for Cytokinesis. Cell Cycle 2012, 11, 1340-1353.

(205) Zhang, J.; Herscovitz, H. Nascent Lipidated Apolipoprotein B Is Transported to the Golgi as an Incompletely Folded Intermediate as Probed by Its Association with 
Network of Endoplasmic Reticulum Molecular Chaperones, GRP94, ERp72, BiP, Calreticulin, and Cyclophilin B. J. Biol. Chem. 2003, 278, 7459-7468.

(206) Kim, J.; Choi, T. G.; Ding, Y.; Kim, Y.; Ha, K. S.; Lee, K. H.; Kang, I.; Ha, J.; Kaufman, R. J.; Lee, J.; Choe, W.; Kim, S. S. Overexpressed Cyclophilin B Suppresses Apoptosis Associated with ROS and Ca2+ Homeostasis after ER Stress. J. Cell Sci. 2008, 121, 3636-3648.

(207) Fang, F.; Flegler, A. J.; Du, P.; Lin, S.; Clevenger, C. V. Expression of Cyclophilin B Is Associated with Malignant Progression and Regulation of Genes Implicated in the Pathogenesis of Breast Cancer. Am. J. Pathol. 2009, 174, 297-308.

(208) Allain, F.; Vanpouille, C.; Carpentier, M.; Slomianny, M.-C.; Durieux, S.; Spik, G. Interaction with Glycosaminoglycans Is Required for Cyclophilin B to Trigger IntegrinMediated Adhesion of Peripheral Blood T Lymphocytes to Extracellular Matrix. Proc. Natl. Acad. Sci. U. S. A. 2002, 99, 2714-2719.

(209) Ward, B. K.; Kumar, P.; Turbett, G. R.; Edmondston, J. E.; Papadimitriou, J. M.; Laing, N. G.; Ingram, D. M.; Minchin, R. F.; Ratajczak, T. Allelic Loss of Cyclophilin 40, an Estrogen Receptor-Associated Immunophilin, in Breast Carcinomas. J. Cancer Res. Clin. Oncol. 2001, 127, 109-115.

(210) Kang, B. H.; Plescia, J.; Dohi, T.; Rosa, J.; Doxsey, S. J.; Altieri, D. C. Regulation of Tumor Cell Mitochondrial Homeostasis by an Organelle-Specific Hsp90 Chaperone Network. Cell 2007, 131, 257-270.

(211) Tavecchio, M.; Lisanti, S.; Lam, A.; Ghosh, J. C.; Martin, N. M.; O’Connell, M.; Weeraratna, A. T.; Kossenkov, A. V; Showe, L. C.; Altieri, D. C. Cyclophilin D Extramitochondrial Signaling Controls Cell Cycle Progression and Chemokine-Directed Cell Motility. J. Biol. Chem. 2013, 288, 5553-5561.

(212) Sicinski, P.; Donaher, J. L.; Parker, S. B.; Li, T.; Fazeli, A.; Gardner, H.; Haslam, S. Z.; Bronson, R. T.; Elledge, S. J.; Weinberg, R. A. Cyclin D1 Provides a Link between Development and Oncogenesis in the Retina and Breast. Cell 1995, 82, 621-630.

(213) Liou, Y.-C.; Ryo, A.; Huang, H.-K.; Lu, P.-J.; Bronson, R.; Fujimori, F.; Uchida, T.; Hunter, T.; Lu, K. P. Loss of Pin1 Function in the Mouse Causes Phenotypes Resembling Cyclin D1-Null Phenotypes. Proc. Natl. Acad. Sci. U. S. A. 2002, 99, 13351340 .

(214) Bao, L.; Kimzey, A.; Sauter, G.; Sowadski, J. M.; Lu, K. P.; Wang, D.-G. Prevalent Overexpression of Prolyl Isomerase Pin1 in Human Cancers. Am. J. Pathol. 2004, 164, 1727-1737.

(215) Girardini, J. E.; Napoli, M.; Piazza, S.; Rustighi, A.; Marotta, C.; Radaelli, E.; Capaci, V.; Jordan, L.; Quinlan, P.; Thompson, A.; Mano, M.; Rosato, A.; Crook, T.; Scanziani, E.; Means, A. R.; Lozano, G.; Schneider, C.; Del Sal, G. A Pin1/mutant p53 Axis Promotes Aggressiveness in Breast Cancer. Cancer Cell 2011, 20, 79-91. 
(216) Wulf, G. M.; Liou, Y.-C.; Ryo, A.; Lee, S. W.; Lu, K. P. Role of Pin1 in the Regulation of p53 Stability and p21 Transactivation, and Cell Cycle Checkpoints in Response to DNA Damage. J. Biol. Chem. 2002, 277, 47976-47979.

(217) Takahashi, K.; Akiyama, H.; Shimazaki, K.; Uchida, C.; Akiyama-Okunuki, H.; Tomita, M.; Fukumoto, M.; Uchida, T. Ablation of a Peptidyl Prolyl Isomerase Pin1 from p53Null Mice Accelerated Thymic Hyperplasia by Increasing the Level of the Intracellular Form of Notch1. Oncogene 2007, 26, 3835-3845.

(218) Toledo, F.; Lee, C. J.; Krummel, K. A.; Rodewald, L.-W.; Liu, C.-W.; Wahl, G. M. Mouse Mutants Reveal That Putative Protein Interaction Sites in the p53 Proline-Rich Domain Are Dispensable for Tumor Suppression. Mol. Cell. Biol. 2007, 27, 1425-1432.

(219) Lu, K. P.; Zhou, X. Z. The Prolyl Isomerase PIN1: A Pivotal New Twist in Phosphorylation Signalling and Disease. Nat. Rev. Mol. Cell Biol. 2007, 8, 904-916.

(220) Van der Horst, A.; Khanna, K. K. The Peptidyl-Prolyl Isomerase Pin1 Regulates Cytokinesis through Cep55. Cancer Res. 2009, 69, 6651-6659.

(221) Harrison, D. E.; Strong, R.; Sharp, Z. D.; Nelson, J. F.; Clinton, M.; Flurkey, K.; Nadon, N. L.; Wilkinson, J. E.; Frenkel, K.; Christy, S.; Pahor, M.; Javors, M. A.; Fernandez, E.; Miller, R. A. Heterogeneous Mice. 2010, 460, 392-395.

(222) Neff, F.; Flores-dominguez, D.; Ryan, D. P.; Horsch, M.; Schröder, S.; Adler, T.; Afonso, L. C.; Aguilar-pimentel, J. A.; Becker, L.; Garrett, L.; Hans, W.; Hettich, M. M.; Holtmeier, R.; Hölter, S. M.; Moreth, K.; Prehn, C.; Puk, O.; Rácz, I.; Rathkolb, B.; Rozman, J.; Naton, B.; Ordemann, R.; Adamski, J.; Beckers, J.; Bekeredjian, R. Rapamycin Extends Murine Lifespan but Has Limited Effects on Aging. 2013, 123.

(223) Flisiak, R.; Feinman, S. V; Jablkowski, M.; Horban, A.; Kryczka, W.; Pawlowska, M.; Heathcote, J. E.; Mazzella, G.; Vandelli, C.; Nicolas-Métral, V.; Grosgurin, P.; Liz, J. S.; Scalfaro, P.; Porchet, H.; Crabbé, R. The Cyclophilin Inhibitor Debio 025 Combined with PEG IFNalpha2a Significantly Reduces Viral Load in Treatment-Naïve Hepatitis C Patients. Hepatology 2009, 49, 1460-1468.

(224) Damsker, J. M.; Okwumabua, I.; Pushkarsky, T.; Arora, K.; Bukrinsky, M. I.; Constant, S. L. Targeting the Chemotactic Function of CD147 Reduces Collagen-Induced Arthritis. Immunology 2009, 126, 55-62.

(225) Arora, K.; Gwinn, W. M.; Bower, M. A.; Watson, A.; Okwumabua, I.; MacDonald, H. R.; Bukrinsky, M. I.; Constant, S. L. Extracellular Cyclophilins Contribute to the Regulation of Inflammatory Responses. J. Immunol. 2005, 175, 517-522.

(226) Hoffmann, H.; Schiene-Fischer, C. Functional Aspects of Extracellular Cyclophilins. Biol. Chem. 2014, 395, 721-735.

(227) Satoh, K.; Fukumoto, Y.; Sugimura, K.; Miura, Y.; Aoki, T.; Nochioka, K.; Tatebe, S.; Miyamichi-Yamamoto, S.; Shimizu, T.; Osaki, S.; Takagi, Y.; Tsuburaya, R.; Ito, Y.; Matsumoto, Y.; Nakayama, M.; Takeda, M.; Takahashi, J.; Ito, K.; Yasuda, S.; 
Shimokawa, H. Plasma Cyclophilin A Is a Novel Biomarker for Coronary Artery Disease. Circ. J. 2013, 77, 447-455.

(228) Felix, R. S.; Colleoni, G. W. B.; Caballero, O. L.; Yamamoto, M.; Almeida, M. S. S.; Andrade, V. C. C.; Chauffaille, M. de L. L. F.; Silva, W. A. da; Begnami, M. D.; Soares, F. A.; Simpson, A. J.; Zago, M. A.; Vettore, A. L. SAGE Analysis Highlights the Importance of $\mathrm{p} 53 \mathrm{csv}$, ddx5, mapkapk2 and ranbp2 to Multiple Myeloma Tumorigenesis. Cancer Lett. 2009, 278, 41-48.

(229) Solár, P.; Sytkowski, A. J. Differentially Expressed Genes Associated with Cisplatin Resistance in Human Ovarian Adenocarcinoma Cell Line A2780. Cancer Lett. 2011, 309, 11-18.

(230) Li, X.-J.; Luo, X.-Q.; Han, B.-W.; Duan, F.-T.; Wei, P.-P.; Chen, Y.-Q. MicroRNA100/99a, Deregulated in Acute Lymphoblastic Leukaemia, Suppress Proliferation and Promote Apoptosis by Regulating the FKBP51 and IGF1R/mTOR Signalling Pathways. Br. J. Cancer 2013, 109, 2189-2198.

(231) Wiemels, J. L.; Bracci, P. M.; Wrensch, M.; Schildkraut, J.; Bondy, M.; Pfefferle, J.; Zhou, M.; Sison, J.; Calvocoressi, L.; Claus, E. B. Assessment of Autoantibodies to Meningioma in a Population-Based Study. Am. J. Epidemiol. 2013, 177, 75-83.

(232) Orr, B.; Riddick, A. C. P.; Stewart, G. D.; Anderson, R. A.; Franco, O. E.; Hayward, S. W.; Thomson, A. A. Identification of Stromally Expressed Molecules in the Prostate by Tag-Profiling of Cancer-Associated Fibroblasts, Normal Fibroblasts and Fetal Prostate. Oncogene 2012, 31, 1130-1142.

(233) Comtesse, N.; Zippel, A.; Walle, S.; Monz, D.; Backes, C.; Fischer, U.; Mayer, J.; Ludwig, N.; Hildebrandt, A.; Keller, A.; Steudel, W.-I.; Lenhof, H.-P.; Meese, E. Complex Humoral Immune Response against a Benign Tumor: Frequent Antibody Response against Specific Antigens as Diagnostic Targets. Proc. Natl. Acad. Sci. U. S. A. $2005,102,9601-9606$.

(234) Yao, Y.-L.; Yang, W.-M. Nuclear Proteins: Promising Targets for Cancer Drugs. Curr. Cancer Drug Targets 2005, 5, 595-610.

(235) Halatsch, M. E.; Löw, S.; Hielscher, T.; Schmidt, U.; Unterberg, A.; Vougioukas, V. I. Epidermal Growth Factor Receptor Pathway Gene Expressions and Biological Response of Glioblastoma Multiforme Cell Lines to Erlotinib. Anticancer Res. 28, 3725-3728.

(236) Lloyd, C.; Grossman, A. The AIP (aryl Hydrocarbon Receptor-Interacting Protein) Gene and Its Relation to the Pathogenesis of Pituitary Adenomas. Endocrine 2014, 46, 387396.

(237) Meza-Zepeda, L. A.; Forus, A.; Lygren, B.; Dahlberg, A. B.; Godager, L. H.; South, A. P.; Marenholz, I.; Lioumi, M.; Flørenes, V. A.; Maelandsmo, G. M.; Serra, M.; Mischke, D.; Nizetic, D.; Ragoussis, J.; Tarkkanen, M.; Nesland, J. M.; Knuutila, S.; Myklebost, O. Positional Cloning Identifies a Novel Cyclophilin as a Candidate Amplified Oncogene in 1q21. Oncogene 2002, 21, 2261-2269. 
(238) Obama, K.; Kato, T.; Hasegawa, S.; Satoh, S.; Nakamura, Y.; Furukawa, Y. Overexpression of Peptidyl-Prolyl Isomerase-like 1 Is Associated with the Growth of Colon Cancer Cells. Clin. Cancer Res. 2006, 12, 70-76.

(239) Tomita-Mitchell, A.; Mahnke, D. K.; Struble, C. A.; Tuffnell, M. E.; Stamm, K. D.; Hidestrand, M.; Harris, S. E.; Goetsch, M. A.; Simpson, P. M.; Bick, D. P.; Broeckel, U.; Pelech, A. N.; Tweddell, J. S.; Mitchell, M. E. Human Gene Copy Number Spectra Analysis in Congenital Heart Malformations. Physiol. Genomics 2012, 44, 518-541.

(240) Brebi, P.; Maldonado, L.; Noordhuis, M. G.; Ili, C.; Leal, P.; Garcia, P.; Brait, M.; Ribas, J.; Michailidi, C.; Perez, J.; Soudry, E.; Tapia, O.; Guzman, P.; Muñoz, S.; Van Neste, L.; Van Criekinge, W.; Irizarry, R.; Sidransky, D.; Roa, J. C.; Guerrero-Preston, R. Genome-Wide Methylation Profiling Reveals Zinc Finger Protein 516 (ZNF516) and FK-506-Binding Protein 6 (FKBP6) Promoters Frequently Methylated in Cervical Neoplasia, Associated with HPV Status and Ethnicity in a Chilean Population. Epigenetics 2014, 9, 308-317.

(241) Wehrens, X. H. T.; Lehnart, S. E.; Huang, F.; Vest, J. A.; Reiken, S. R.; Mohler, P. J.; Sun, J.; Guatimosim, S.; Song, L. S.; Rosemblit, N.; D’Armiento, J. M.; Napolitano, C.; Memmi, M.; Priori, S. G.; Lederer, W. J.; Marks, A. R. FKBP12.6 Deficiency and Defective Calcium Release Channel (ryanodine Receptor) Function Linked to ExerciseInduced Sudden Cardiac Death. Cell 2003, 113, 829-840.

(242) Helmer, R. A.; Martínez-Zaguilán, R.; Dertien, J. S.; Fulford, C.; Foreman, O.; Peiris, V.; Chilton, B. S. Helicase-like Transcription Factor (Hltf) Regulates G2/M Transition, Wt1/Gata4/Hif-1a Cardiac Transcription Networks, and Collagen Biogenesis. PLoS One 2013, 8, e80461.

(243) Periyasamy, S.; Hinds, T.; Shemshedini, L.; Shou, W.; Sanchez, E. R. FKBP51 and Cyp40 Are Positive Regulators of Androgen-Dependent Prostate Cancer Cell Growth and the Targets of FK506 and Cyclosporin A. Oncogene 2010, 29, 1691-1701. 


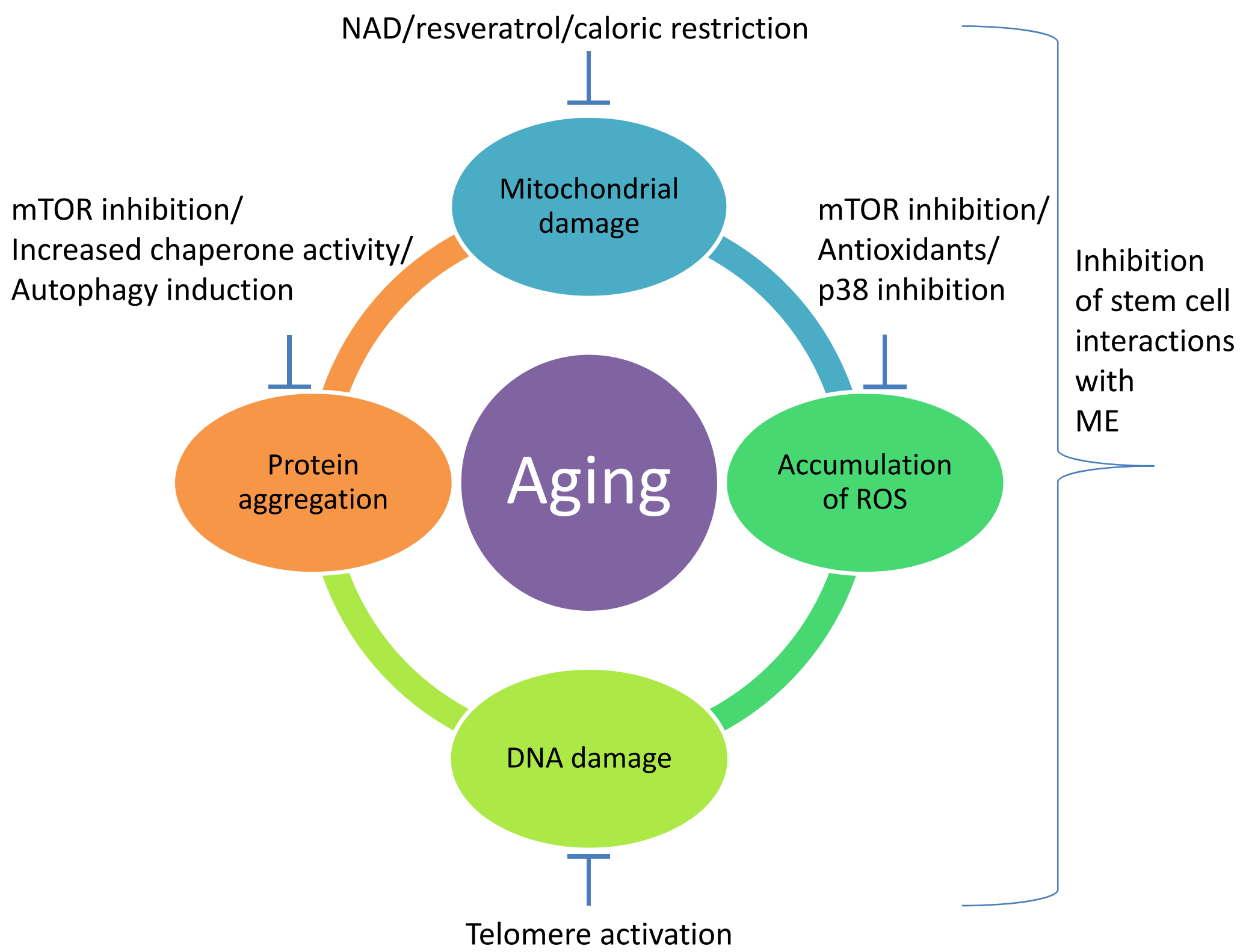

Figure 1. Different mechanisms involved in aging and the associated targeting strategies. $M E$ - microenvironment; NAD - nicotaminamide adenine dinucleotide (the sirtuin pathway activator). 


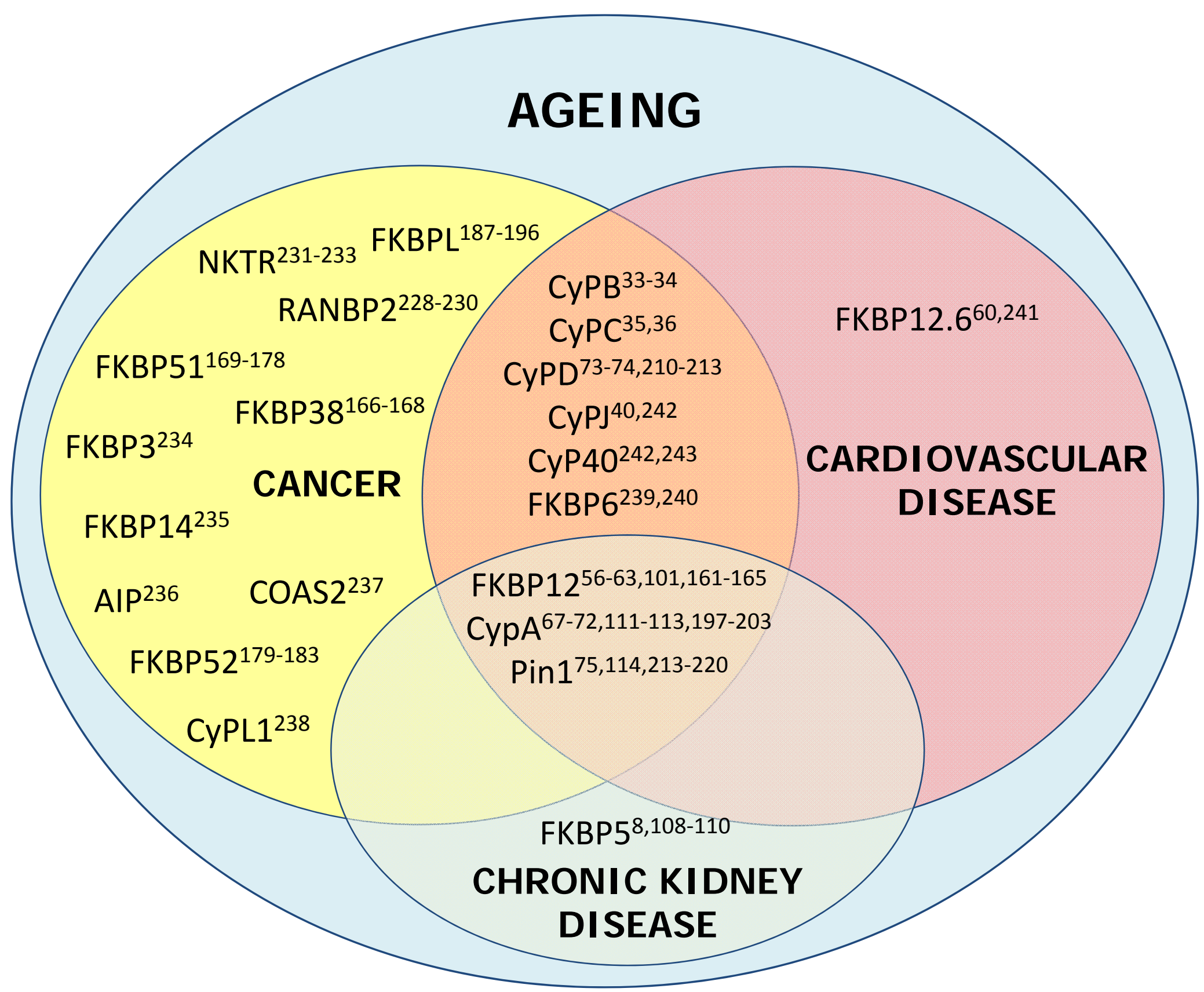

Figure 2. PPlases in aging and age-related diseases (cancer, cardiovascular disease and chronic kidney disease). 


\begin{tabular}{|c|c|c|c|}
\hline $\begin{array}{l}\text { Age-Related } \\
\text { Diseases }\end{array}$ & PPIase & Mechanisms & References \\
\hline $\begin{array}{l}\text { Cardiovascular } \\
\text { diseases }\end{array}$ & $\begin{array}{l}\text { FKBP12 } \\
\text { Cyclophilin A } \\
\text { Cyclophilin D } \\
\text { Pin1 }\end{array}$ & $\begin{array}{l}\text { Calcium augmentation; RyRs channel regulation; hypertension } \\
\text { Pro-inflammatory; generation of ROS; atherosclerosis, ACS biomarker } \\
\text { Stabilisation of the mPTP complex; } \\
\text { Binds to Akt, MEK and Raf-1 }\end{array}$ & $\begin{array}{l}56-63 \\
67-72 \\
73,74 \\
75\end{array}$ \\
\hline Type II diabetes & FKBP51 & $\begin{array}{l}\text { Associated with T2D phenotype; gene expression changes in response to stress } \\
\text { and diet } \\
\text { Biomarker of inflammation in T2D and vascular complications }\end{array}$ & $\begin{array}{l}85,86 \\
70,87\end{array}$ \\
\hline $\begin{array}{l}\text { Chronic Kidney } \\
\text { Disease }\end{array}$ & $\begin{array}{l}\text { FKBP12 } \\
\text { FKBP51 } \\
\text { Cyclophilin A } \\
\text { Pin1 }\end{array}$ & $\begin{array}{l}\text { Calcium oxylate crystal deposition } \\
\text { DNA methylation; expression induced by aldosterone } \\
\text { Association with renal acidosis, diabetic nephropathy, renal cell carcinoma } \\
\text { Downregulation in secondary parathyroidism, complication of CKD }\end{array}$ & \begin{tabular}{l|}
101 \\
$108-110$ \\
$111-113$ \\
114 \\
\end{tabular} \\
\hline Neurodegeneration & $\begin{array}{l}\text { FKBP12 } \\
\text { FKBP38 } \\
\text { FKBP51 } \\
\text { FKBP52 } \\
\text { FKBPL } \\
\text { Cyclophilin A } \\
\text { Cyclophilin D } \\
\text { Pin1 }\end{array}$ & $\begin{array}{l}\text { Augmentation of calcium and APP processing; downregulation in Alzheimer's } \\
\text { disease } \\
\text { Inhibition of mitochondrial Bcl-2 in the brain } \\
\text { Microtubule stabilisation through Hsp90 dephosphorylation of tau } \\
\text { Microtubule destabilisation and tubulin depolymerisation } \\
\text { Protective role in Alzheimer's disease } \\
\text { Regulation of inflammatory pathways, NF- } \kappa \mathrm{B} \text { and MMP-9; release of } \\
\text { neurotoxins } \\
\text { Stabilisation of mPTP complex; regulation of A } \beta \text { protein activity within mPTP } \\
\text { complex } \\
\text { Stabilisation and regulation of tau and A } \beta\end{array}$ & $\begin{array}{l}130-134 \\
135-138 \\
139-141 \\
132,141-146 \\
147 \\
148 \\
149 \\
42,150 \\
\end{array}$ \\
\hline $\begin{array}{l}\text { Age-related } \\
\text { macular } \\
\text { degeneration }\end{array}$ & FKBPL & AMD susceptibility gene & 154,155 \\
\hline Cancer & $\begin{array}{l}\text { FKBP12 } \\
\text { FKBP38 }\end{array}$ & $\begin{array}{l}\text { Apoptosis via TGF- } \beta \text { mitochondrial pathway } \\
\text { Chemoresistance via Bcl-2 }\end{array}$ & $\begin{array}{l}161-165 \\
166-168\end{array}$ \\
\hline
\end{tabular}




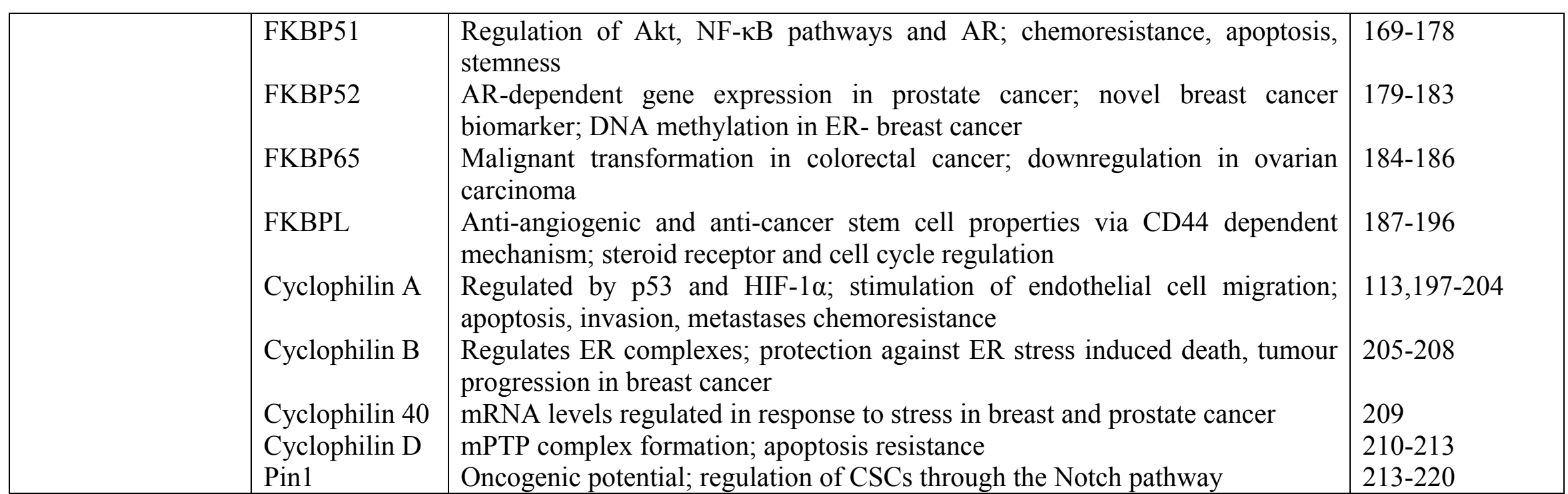

Table 1: Summary of the roles of PPIases in the age-related diseases. ROS - reactive oxygen species; ACS - acute coronary syndrome; $M E K$ - mitogen activated protein kinase; $m P T P$ - mitochondrial permeability transition pore; APP-amyloid precursor protein; T2D - type II diabetes; $R y R s$-ryanodine receptors; AR-androgen receptor; HIF-1 $\alpha$-hypoxia inducible factor $1 \alpha$; ER-oestrogen receptor; CSCs-cancer stem cells 